\title{
REVIEW \\ Census and evaluation of p53 target genes
}

\author{
M Fischer ${ }^{1,2,3}$
}

The tumor suppressor p53 functions primarily as a transcription factor. Mutation of the TP53 gene alters its response pathway, and is central to the development of many cancers. The discovery of a large number of p53 target genes, which confer p53's tumor suppressor function, has led to increasingly complex models of p53 function. Recent meta-analysis approaches, however, are simplifying our understanding of how p53 functions as a transcription factor. In the survey presented here, a total set of 3661 direct p53 target genes is identified that comprise 3509 potential targets from 13 high-throughput studies, and 346 target genes from individual gene analyses. Comparison of the p53 target genes reported in individual studies with those identified in 13 highthroughput studies reveals limited consistency. Here, p53 target genes have been evaluated based on the meta-analysis data, and the results show that high-confidence p53 target genes are involved in multiple cellular responses, including cell cycle arrest, DNA repair, apoptosis, metabolism, autophagy, mRNA translation and feedback mechanisms. However, many p53 target genes are identified only in a small number of studies and have a higher likelihood of being false positives. While numerous mechanisms have been proposed for mediating gene regulation in response to $\mathrm{p} 53$, recent advances in our understanding of p53 function show that p53 itself is solely an activator of transcription, and gene downregulation by p53 is indirect and requires p21. Taking into account the function of $\mathrm{p} 53$ as an activator of transcription, recent results point to an unsophisticated means of regulation.

Oncogene (2017) 36, 3943-3956; doi:10.1038/onc.2016.502; published online 13 March 2017

\section{INTRODUCTION}

The tumor suppressor p53 and its encoding genes are the most studied protein and gene in literature, with a total of more than 80000 entries in PubMed. p53 was mistakenly discovered almost four decades ago as an oncogene that is overexpressed in cancer, and has since become known as the most important tumor suppressor, and 'the guardian of the genome'.1,2 This is evidenced by reports that TP53, the gene that encodes for $\mathrm{p} 53$, is the most frequently mutated gene in cancer. ${ }^{3} \mathrm{p} 53$ is activated in response to stress signals-DNA damage, oncogene activation, ribosomal stress and hypoxia ${ }^{4}$ —and leads to growth suppression by inducing cell cycle arrest or cell death. The prevailing function of the p53 tumor suppressor is the transcriptional control of target genes that regulate numerous cellular processes, including cell cycle and apoptosis. ${ }^{5,6}$ Typically, p53 binds to the target genes as a tetramer, which comprises two dimers that each binds a decameric half-site with the consensus sequence RRRCWWGYYY $(\mathrm{R}=\mathrm{A} / \mathrm{G}, \mathrm{W}=\mathrm{A} / \mathrm{T}, \mathrm{Y}=\mathrm{C} / \mathrm{T}){ }^{7-10}$ The discovery of the first p53 target genes, including CDKN1A (p21, CIP1, WAF1), ${ }^{11,12}$ GADD45A ${ }^{13}$ and $M D M 2,{ }^{14,15}$ inspired numerous researchers to identify additional genes that mediate the tumor suppressor function. Recent genome-wide analyses have identified from one hundred ${ }^{16}$ up to thousands ${ }^{17}$ of potential p53 target genes.

The aim of the present survey is to compile an updated list of p53 target genes from individual gene analyses and highthroughput studies that will serve as a resource, and to evaluate the regulation of these genes based on the frequency of their identification in independent studies. Results from a recent metaanalysis of 20 genome-wide p53 gene expression profiles, and 15 p53 binding profiles, document that many p53 target genes are regulated across cell types as well as treatments. ${ }^{18}$ Moreover, a comparison of binding studies shows that functional p53 binding is independent of cell type and treatment. ${ }^{19}$ In the present survey, a p53 target gene is defined as a protein-coding gene that is differentially regulated following p53 activation or inactivation, and that is bound by p53 near the gene locus.

\section{SURVEY OF 346 TARGET GENES DERIVED FROM 319 INDIVIDUAL GENE STUDIES}

Similar to the discovery of the first p53 target genes, many additional p53 targets have been identified in studies that focused on one up to a few individual genes. The criterion of a target gene that is bound as well as regulated by p53 is met by 346 genes described in 319 such 'individual gene studies' (Supplementary Table S1). Taking into consideration that some of these studies investigated several target genes, and that some target genes were reported in more than one study, a total of 399 gene-study pairs were found (Supplementary Table S1). More than one study on a target gene was included in the list if it provided information on the p53-dependent regulation that added to or was different from what was reported in the initial study. The 319 individual studies were published between 1992 and 2016, with a maximum of 26 studies published in 2006 (Figure 1a). Of the 346 genes, 246 were reported as activated by p53, 91 as repressed and 9 as both activated and repressed (Figure 1b). The 319 studies (399 gene-study pairs) investigated 358 human genes, 47 mouse genes, 5 rat genes and 1 bovine gene (Figure 1c). When a study investigated gene regulation in multiple species, the human data was focused.

\footnotetext{
${ }^{1}$ Molecular Oncology, Medical School, University of Leipzig, Leipzig, Germany; ${ }^{2}$ Department of Medical Oncology, Dana-Farber Cancer Institute, Boston, MA, USA and ${ }^{3}$ Department of Medicine, Brigham and Women's Hospital, Harvard Medical School, Boston, MA, USA. Correspondence: Dr M Fischer, Molecular Oncology, University of Leipzig, Semmelweisstrasse14, Leipzig 04103 Germany.

E-mail: Martin.Fischer@medizin.uni-leipzig.de or Martin_Fischer@dfci.harvard.edu

Received 10 October 2016; revised 23 November 2016; accepted 29 November 2016; published online 13 March 2017
} 

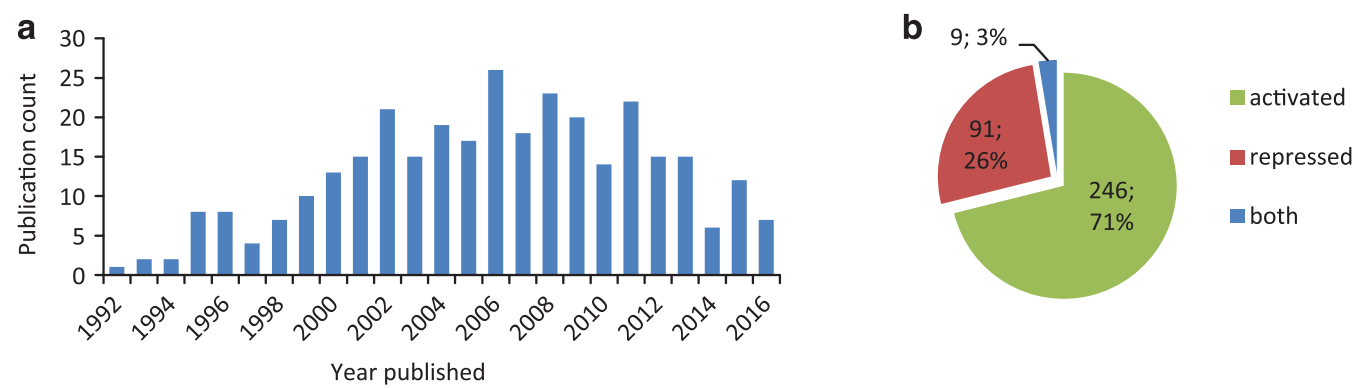

C

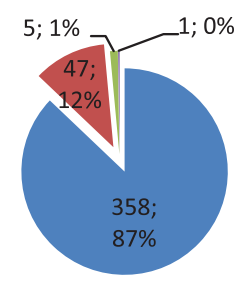

numan

mouse

rat

a bovine

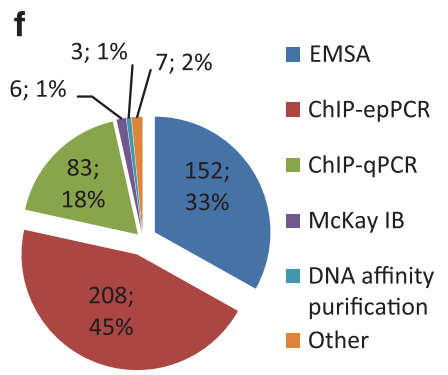

d

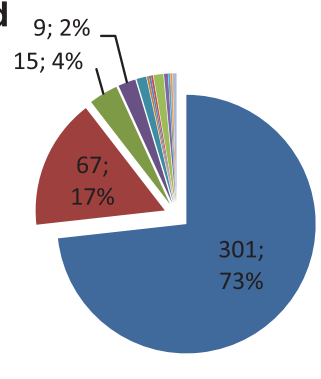

promoter

- intron1

- intron2

- intron3

intron4

- intron9

intron11

intron13

exon1

- exon2

exon3

3'UTR

downstream

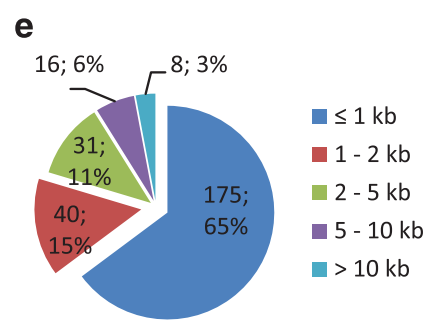

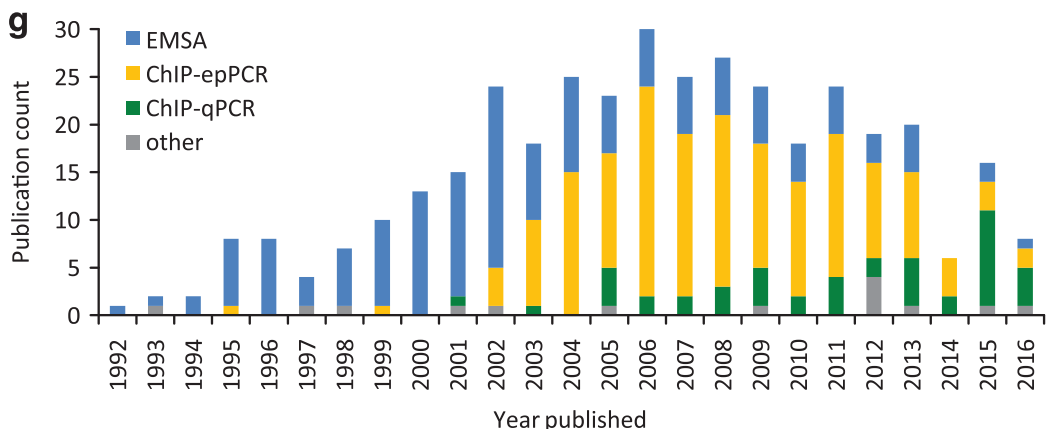

Figure 1. Survey of 346 target genes derived from 319 individual gene studies. (a) The number of studies reporting individual p53 target genes published in a particular year. (b) Genes were reported as activated, repressed or both activated and repressed by p53. (c) Experiments were carried out in cells from human, mouse, rat or bovine. Some studies used cells from more than one species. (d) Binding of p53 is located in different parts of the gene. (e) p53 binding sites are located in varying distances from the TSS. Some genes display multiple p53 binding sites. (f) Various methods have been used to identify p53 binding sites. Some studies used more than one method. (g) The number of publications that used a particular method to identify p53 binding compared with the publication year. Some studies used multiple methods.

p53 most frequently binds in the promoter region (5'-untranslated region (UTR) and upstream) of genes. Introns (particularly intron 1) also frequently harbor p53 binding sites, whereas p53 seldom binds to the coding region (Figure 1d). Precise location of the p53 binding site has been reported for 266 of the 399 gene-study pairs. In general, the number of p53 binding events decreases with increasing distance from the transcriptional start site (TSS). Proximal p53 binding — that is, within $1 \mathrm{~kb}$ from the TSS-occurs most frequently, whereas distal binding-at $>10 \mathrm{~kb}$ from the TSS-is rarely reported (Figure 1e). It is important to note, however, that studies on individual genes are biased for analyzing promoters. The most common technique used to identify p53 binding is chromatin immunoprecipitation followed by end point PCR (ChIP-epPCR), which was applied 208 times. Electromobility shift assays (applied 152 times) and ChIP followed by real-time PCR (ChIP-qPCR, applied 83 times) have also been frequently used. Other techniques such as the McKay immunoblots (McKay IB, applied six times) and DNA affinity purifications (applied three times) are rarely used (Figure 1f). Use of the ChIP technique replaced use of electromobility shift assay over time, but the outdated ChIP-epPCR has not yet been fully replaced by ChIP-qPCR (Figure 1g).

\section{SURVEY OF 3509 TARGET GENES DERIVED FROM 16 HIGH- THROUGHPUT DATA SETS}

In recent years, genome-wide analyses aimed at identifying p53 target genes have each identified shared candidates, as well as those that are unique. ${ }^{16,18,20-30}$ In these analyses, candidate p53 target genes were uncovered by integrating p53-dependent gene expression profiles with p53 binding profiles. As mentioned above, genes that are regulated and bound by $\mathrm{p} 53$ are considered to be candidate p53 target genes. Given that three studies harbored two data sets each, ${ }^{20,22,26} 16$ data sets were extracted from 13 genome-wide studies of p53 target genes, ${ }^{16,18,20-30}$ yielding a total of 3509 candidate p53 target genes in the 16 data sets (Supplementary Table S2). From $121^{16}$ to $1341^{26}$ candidate p53 target genes were documented in the individual data sets. Notably, the majority of genes (2261 out of $3509 ; 64.4 \%$ ) was identified exclusively in one data set (Figure 2a). Only two genesCDKN $1 A^{11,12}$ and $R R M 2 B^{31}$ - were identified in all 16 data sets. This is particularly surprising, given that some data sets were derived from the same combination of cell type and treatment (HCT116 cells treated with 5-FU ${ }^{16,29}$ and MCF-7 cells treated with Nutlin- $3 \mathrm{a}^{21,25}$ ), and indicates that the individual data sets harbor numerous false positives and false negatives. Table 1 displays the 
a

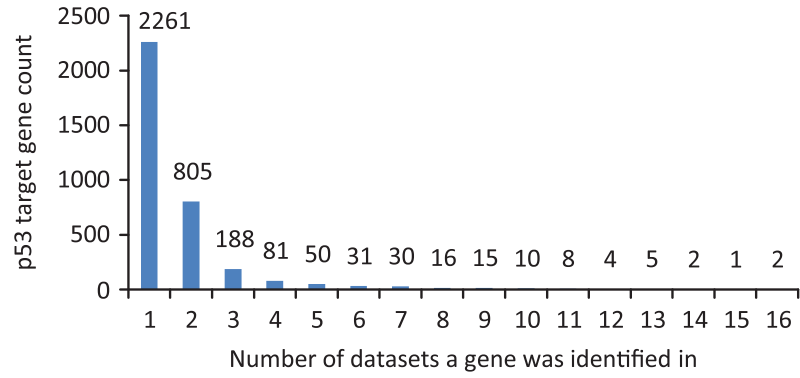

c

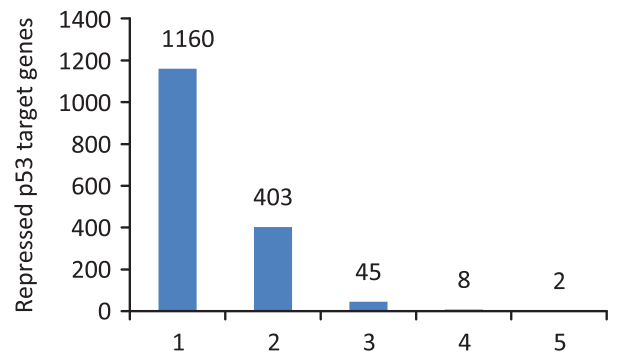

b

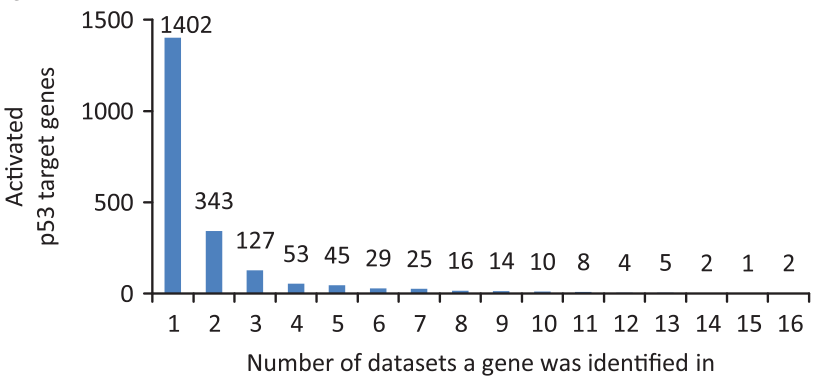

Number of datasets a gene was identified in

Figure 2. Survey of 3509 target genes derived from 16 high-throughput data sets. (a) The number of potential p53 targets is compared with the number of data sets that commonly identify them. (b) The number of genes is displayed that is identified by an increasing number of data sets as being directly activated by p53. (c) The number of genes is displayed that is identified by an increasing number of data sets as being directly repressed by $\mathrm{p} 53$.

top 116 genes that are identified as p53-activated targets in at least six data sets. In addition to CDKN1A and RRM2B, well-known p53 target genes were identified in the majority of data sets, including MDM2, ${ }^{14,15}$ GDF15, ${ }^{32}$ SUSD6 (TMPS, DRAGO, KIAA0247), ${ }^{33,34}$ GADD45A, ${ }^{13}$ PLK3, ${ }^{35}$ BTG2, $^{36}$ TIGAR (C12orf5), ${ }^{35,37}$ TNFRSF10B, ${ }^{38,39}$ PPM $1 D,^{40}$ BAX $^{41-43}{ }^{4}{ }^{4}{ }_{1}^{44}$ PLK2 ${ }_{1}^{45}$ SESN $1,{ }^{46}$ $F S^{47-49}$ and $K I T L G^{50}$ (Supplementary Table S2). Well-known p53 target genes that did not meet the criteria of a published p53 target (this occurred usually because p53 gene binding was not investigated; see above) included SFN (14-3-3 sigma), ${ }^{51}$ SESN2, ${ }^{52}$ TNFRSF10C ${ }^{39}$ and TNFRSF10D, ${ }^{39}$ and these genes were identified in multiple data sets as well. Thus, the number of data sets that agree on a gene being a p53 target represents a ranking of confidence, which is supported by recent meta-analysis results. ${ }^{18}$ Genes that were identified only in a small number of data sets are more likely to be false positives.

When p53 target genes are grouped into those that are activated by or repressed by $\mathrm{p} 53$, it is evident that the majority of data sets exclusively identified target genes that are activated by p53. In contrast, target genes that are repressed by p53 were not commonly identified (Figures $2 b$ and $c$ ). This finding is in agreement with the current model that describes p53 solely as a transcriptional activator, and not as repressor. ${ }^{53}$

\section{TARGET GENE ACTIVATION BY P53}

The p53 tumor suppressor binds target genes through p53 response elements (REs) that comprise two decameric half-sites with the consensus sequence RRRCWWGYYY, separated by a spacer of $0-13 \mathrm{bp}$. In addition, results from multiple studies suggest that p53 can bind and transactivate target genes through noncanonical binding sites, particularly through half-sites. ${ }^{22,54-56}$ A recent comparison of multiple genome-wide p53 binding studies, however, showed that spacers and half-sites have no role in functional p53 binding. ${ }^{19}$

Activation of $\mathrm{p} 53$ is induced by cell stress including DNA damage, oncogene activation, ribosomal stress or hypoxia. ${ }^{4}$ DNA damage, for example, initiates a series of p53 pulses that ultimately lead to target gene activation. ${ }^{57}$ The $\mathrm{p} 53$ transcription factor uses two transactivation domains to drive gene expression ${ }^{58}$ and the transactivation of target genes requires cooperative interaction between the p53 molecules at DNA REs. ${ }^{23,59}$ Target genes were reported to be activated by $\mathrm{p} 53$ with varying kinetics through stimulus- and promoter-specific recruitment of transcription initiation components and polymerase $1 .^{60-63}$ Genome-wide data, however, do not support promoter-specific activities of p53, but instead suggest unsophisticated p53 binding. ${ }^{19}$

\section{P53 BINDING: LOCATION, LOCATION, LOCATION}

How differences in the location of p53 binding, relative to the TSS of a given gene, influence the gene's regulation is not known. To identify p53 target genes, the genome-wide studies have used thresholds for p53 binding that range from $5 \mathrm{~kb}^{22}$ to $100 \mathrm{~kb}^{16}$ relative to the TSS, but the general consensus is that the number of p53 binding events declines with increasing distance from the TSS.

Analysis of the 346 reported p53 target genes shows that binding to most p53 target genes occurs within $1 \mathrm{~kb}$ of the TSS (Figure 1e), which is in agreement with results from a previous smaller census of p53 target genes that reported a decline in transactivation potential with distance from the TSS. ${ }^{5}$ This observation is further supported by the control of gene transcription largely through proximal promoters. ${ }^{64} \mathrm{~A}$ recent genome-wide meta-analysis also found that proximal p53 binding, within $2.5 \mathrm{~kb}$ from the TSS, strongly correlates with transactivation of p53 target genes. ${ }^{18}$ Of note, the meta-analysis data provides evidence that distal p53 binding also correlates with target gene activation, although to a lesser degree. ${ }^{18}$ And, long-distance transactivation is reportedly mediated by the binding of p53 to enhancers. $^{30,65,66}$ Finally, gene downregulation through distal enhancer interference by p53 binding has been reported for mouse embryonic stem cells, ${ }^{17}$ but is not supported by data from humans. $^{18,19}$

The finding that $\mathrm{p} 53$ binding occurs at intronic sites (Figure 1d) indicates that p53 can promote alternative transcription initiation, which leads to the formation of transcripts that differ in the length 
Table 1. Top 116 genes identified as activated p53 targets in at least 6 out of 16 genome-wide data sets

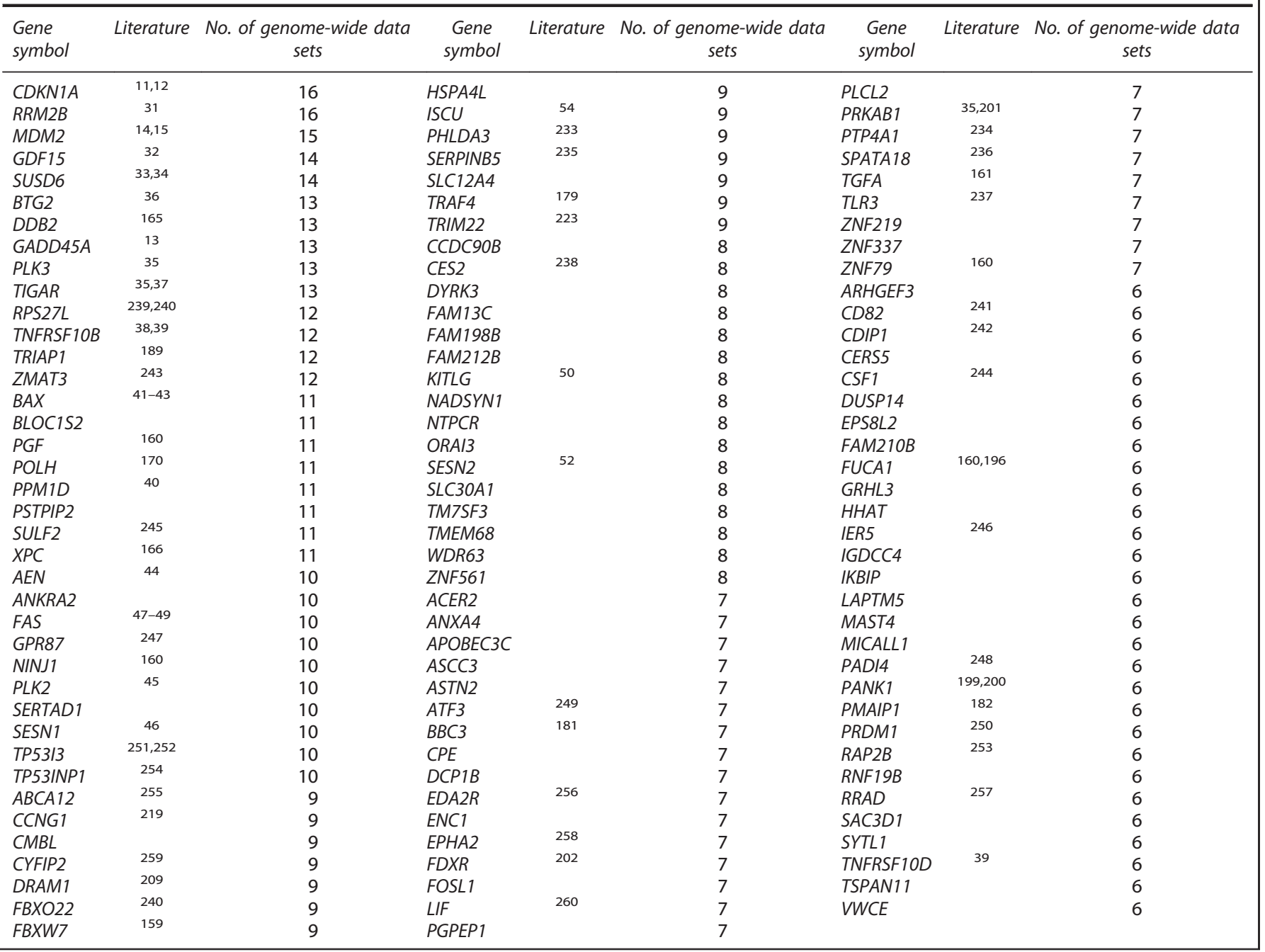

of their $5^{\prime}$-UTR, or their first exon. In case of MDM2, for example, p53 binding to the first intron leads to the formation of transcripts that differ from the constitutionally expressed MDM2 isoform. ${ }^{67,68}$ Thus, alternate transcription initiation enables p53 to induce transcripts that may differ in their function from the longest isoforms.

\section{TRANSCRIPTIONAL DOWNREGULATION BY P53}

Numerous mechanisms have been proposed for mediating gene downregulation in response to p53 activation ${ }^{69-72}$ (Figure 3). In 1993, p53 was first reported to bind to coactivators, including the TATA-box binding protein, ${ }^{73,74}$ the CCAAT-box binding factor $(\mathrm{NF}-\mathrm{Y})^{75}$ and specificity protein 1 (Sp1) that binds to GC-boxes, ${ }^{76}$ and to interfere with their transactivator function. While many additional coactivators are believed to be blocked by $\mathrm{p} 53, \mathrm{NF}-\mathrm{Y}^{77}$ and $\mathrm{Sp} 1^{78,79}$ are the coactivators most commonly linked to p53dependent gene downregulation through a mechanism of p53 interference. Note, however, that interference of p53 with coactivators is not supported by results of genome-wide analyses: $^{.3}$ phylogenetically conserved TATA-boxes, CCAATboxes and GC-boxes are not enriched among genes that are downregulated in response to $\mathrm{p} 53$ activation.

The most commonly reported model for p53-dependent gene downregulation involves the direct binding of p53 to the target gene promoter (Supplementary Table S1). In these cases, p53 binds either through a consensus p53 RE, ${ }^{80,81}$ a head-to-tail oriented p53 RE, ${ }^{82-84}$ a p53 RE with changed dinucleotide core ${ }^{85}$ or by piggy-backing on coactivators, such as NF-Y $\mathrm{Y}^{86}$ or Sp1. ${ }^{87,88}$ Reports of direct repression of many target genes by $p 53$, however, have been contradicted in the literature (Table 2). The current model describes p53 solely as a transcriptional activator and not as repressor, ${ }^{53}$ and is supported by multiple genome-wide analyses. ${ }^{18,19,23,24,89}$ The survey presented here also shows little conformity among potential p53 repressed targets (Figure $2 \mathrm{c}$ ).

In 1997, the cyclin-dependent kinase (CDK) inhibitor p21 (CDKN1A) was initially documented to be necessary for p53dependent downregulation of the cell cycle genes CDK1 (Cdc2) and Cyclin A2. ${ }^{90,91}$ Following these reports, numerous cell cycle genes were found to be downregulated via the p53-p21 pathway. ${ }^{92-97}$ From cell cycle research, we know that CDKs are crucial for inactivation of repressor complexes formed by the pocket proteins RB, p107 and p130, and by the E2F transcription factors. Consistent with this notion, p130 and E2F4 are recruited to cell cycle gene promoters when p21 is activated by $p 53 .^{98,99}$ $\mathrm{RB}$, too, is important for p53-dependent downregulation of multiple genes. ${ }^{100-103}$ The pocket proteins p107 and p130, together with E2F4, are members of the multiprotein repressor complex DREAM that binds cell cycle genes during quiescence. ${ }^{104-106}$ Further, the DREAM complex is stabilized and recruited to target gene promoters when p21 is activated by p53. ${ }^{107-114}$ However, how DREAM and RB coordinate their efforts to mediate p53- 

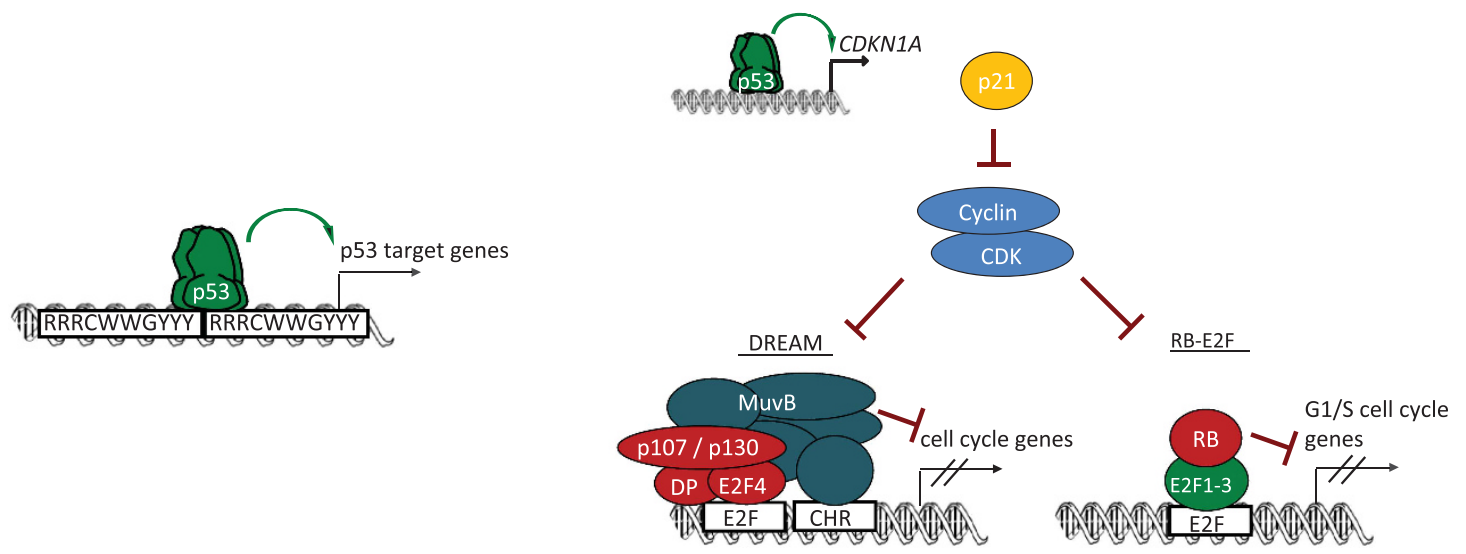

b
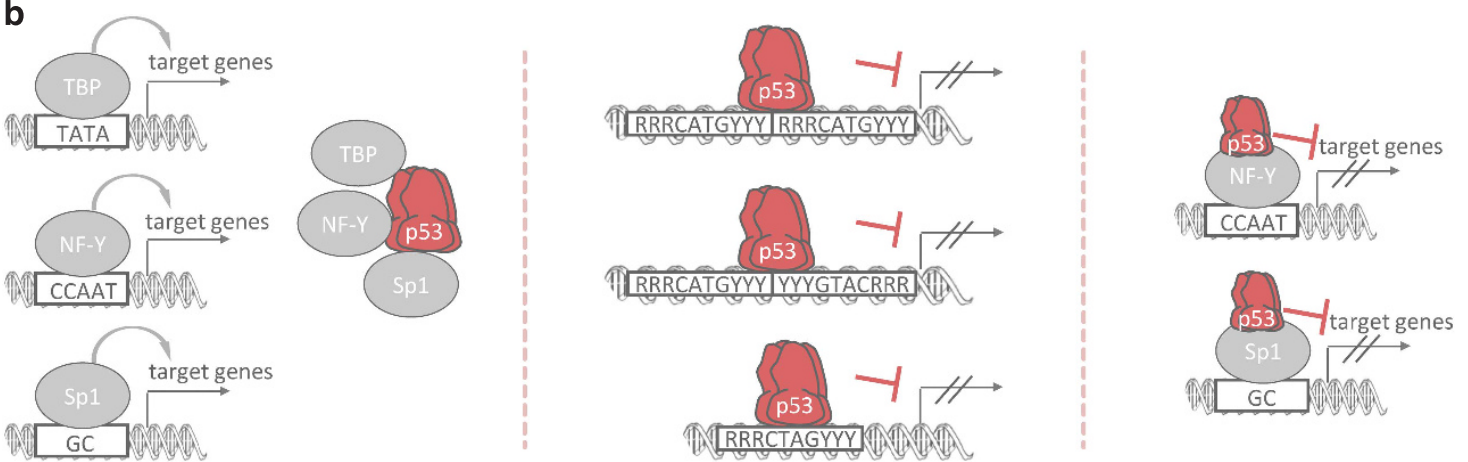

Figure 3. Mechanisms of p53-mediated transcription control. (a) Mechanisms involving direct target gene activation by p53 and indirect repression through p53-p21-DREAM/RB are supported by genome-wide data. (b) Mechanisms involving the sequestration of coactivators or direct target gene repression by $\mathrm{p} 53$ are not supported by genome-wide data.

dependent gene downregulation is not fully understood. Genome-wide analyses show that most genes downregulated by p53 are cell cycle genes ${ }^{115}$ and targets of the DREAM complex. ${ }^{18}$ Recent results from p21-knockout cells show that, in general, p21 is required for p53-dependent gene downregulation. ${ }^{18,116}$ Collectively, these results indicate that p21 not only mediates p53dependent downregulation of cell cycle genes but also identifies p21 as being part of most, if not all, pathways that mediate gene downregulation by $\mathrm{p} 53$.

E2F7 is a p53 target gene ${ }^{117}$ and encodes a transcriptional regulator of cell cycle genes, ${ }^{118}$ and its role in mediating p53-dependent downregulation is unclear: Carvajal et al. ${ }^{117}$ reported that E2F7 and p21 are required for p53-dependent downregulation of G1/S cell cycle genes; Schlereth et al., ${ }^{59}$ however, found that E2F7 but not p21 was required for mediating downregulation of $\mathrm{G} 1 / \mathrm{S}$ genes, and Benson et al. ${ }^{119}$ revealed that E2F7 likely is not involved in p53-mediated downregulation of cell cycle genes. Notably, genome-wide data supports the possibility that E2F7, in conjunction with DREAM and RB, downregulates G1/S cell cycle genes in response to p53 activation. ${ }^{53}$

Several noncoding RNAs were reported to mediate p53dependent gene regulation-these include microRNAs ${ }^{120}$ and long noncoding RNAs, ${ }^{121}$ such as TUG1, ${ }^{122,123}$ miR-34, ${ }^{124}$ lincRNAp21, ${ }^{125}$ PANDA $^{126}$ and PINT. ${ }^{127}$ Nonetheless, results based on different experimental approaches have limited consistency. For example, results of experiments that used overexpression or knockdown of miR-34 or lincRNA-p2 $1^{124,125}$ barely overlapped with those that used knockout mice. ${ }^{128,129}$ In the case of lincRNA-p21, the low stability and low copy numbers found make it unlikely that lincRNA-p21 directly regulates many target genes. ${ }^{129}$ Furthermore, many lincRNA-p21 target genes identified in mice ${ }^{125}$ are not regulated by $\mathrm{p} 53$ in humans. ${ }^{53}$ Given that gene downregulation by $\mathrm{p} 53$ is governed by $\mathrm{p} 21$ in general, ${ }^{18,116}$ it remains open for future investigations how noncoding RNAs coordinate their efforts with p21, to mediate gene downregulation by $\mathrm{p} 53$. One such mechanism was suggested for lincRNA-p21, which supports p21 upregulation in response to p53 activation. ${ }^{129}$

\section{EVALUATING REPRODUCIBILITY}

Table 2 shows the contradictions and limited reproducibility found in the literature on p53-dependently repressed genes. Individual gene studies and genome-wide analyses report potential targets that are directly repressed by $\mathrm{p} 53$, and that are likely to be false positives (Supplementary Table S1 and Figure 2c). Reproducibility issues, however, are not limited to reports on directly repressed p53 target genes: of 242 protein-coding genes that are reportedly directly activated by p53 (Supplementary Table S1), only 150 (62.0\%) have been identified in at least one out of 16 genomewide data sets (Supplementary Table S2). These 16 genome-wide data sets cover a broad range of cell types and treatments, and recent findings indicate that p53 binds target genes independent of cell type and treatment. ${ }^{19}$ However, 92 of the genes that are reportedly directly activated p53 targets are not supported by any of the 16 genome-wide data sets, including BNIP3L, ${ }^{130}$ ESR1, ${ }^{131}$ FDFT1, FDPS, LDLR, ${ }^{132}$ PARK2, ${ }^{133}$ POMC, ${ }^{134}$ SHBG ${ }^{135}$ Toll-like receptors 2, 4, 5, 8 and $10^{136}$ and ULK1 and $U L K 2^{137}$ (Supplementary Table S2). The reason behind this lack of reproducibility is unclear, but it points to a need for caution in interpreting research findings that have not been reproduced by independent approaches and by a number of investigators. It is well known that research findings can have limited 
Table 2. Genes reported as being directly repressed by $\mathrm{p} 53$, and contradictory findings

\begin{tabular}{|c|c|c|}
\hline Gene & $\begin{array}{l}\text { Reports of direct } \\
\text { repression }\end{array}$ & Reported contradictions \\
\hline$A B C B 1(M D R 1)$ & 82 & $\begin{array}{l}\text { Activated, not repressed } \\
\text { Not bound or regulated by } p 53^{53}\end{array}$ \\
\hline ANLN & 262 & Repression requires $\mathrm{p} 107 / \mathrm{p} 130^{263}$ \\
\hline$B C L 2$ & 190,191 & Not bound or regulated by $p 53^{53}$ \\
\hline BIRC5 (Survivin) & $264-267$ & $\begin{array}{l}\text { Not bound by } \mathrm{p} 53^{92,107,268} \\
\text { Repression requires } \mathrm{p} 21^{92,93,107} \\
\text { Repression requires } \mathrm{p} 107 / \mathrm{p} 130^{263}\end{array}$ \\
\hline BNIP3 & 269 & Not bound or regulated by $p 53^{53}$ \\
\hline CCNB1 & 270,271 & $\begin{array}{l}\text { Not bound by } \mathrm{p} 53^{53,108} \\
\text { Repression requires } \\
\text { p2 } 1^{53,92,94,100,108}\end{array}$ \\
\hline CCNB2 & 86 & $\begin{array}{l}\text { Repression requires } \mathrm{p} 107 / \mathrm{p} 130^{263} \\
\text { Repression requires } \mathrm{p} 21^{95,101,109} \\
\text { Repression requires } \mathrm{p} 107 / \mathrm{p} 130^{263}\end{array}$ \\
\hline$C D 44$ & 83 & $\begin{array}{l}\text { Not bound by } p 53^{53} \\
\text { Not regulated by } p 53^{53,272}\end{array}$ \\
\hline$C D C 20$ & 273 & $\begin{array}{l}\text { Not bound by } \mathrm{p} 53^{53} \\
\text { Repression requires } \mathrm{p} 21^{93,96} \\
\text { Repression requires } \mathrm{p} 107 / \mathrm{p} 130^{263}\end{array}$ \\
\hline$C D C 25 B$ & 274 & Repression requires $\mathrm{p} 21^{95}$ \\
\hline$C D C 25 \mathrm{C}$ & 275,276 & $\begin{array}{l}\text { Not bound by } \mathrm{p} 53^{107} \\
\text { Repression requires } \mathrm{p} 21^{92,107} \\
\text { Repression requires } \mathrm{p} 107 / \mathrm{p} 130^{263}\end{array}$ \\
\hline CDK1 (CDC2) & 86,276 & $\begin{array}{l}\text { Not bound by } \mathrm{p} 53^{53} \\
\text { Repression requires } \\
\text { p2 } 21^{53,90,92,94,98,100,101} \\
\text { Repression requires } \mathrm{p} 107 / \mathrm{p} 130^{263}\end{array}$ \\
\hline CKS2 & 277 & Repression requires $\mathrm{p} 107 / \mathrm{p} 130^{263}$ \\
\hline CRYZ & 262,278 & Not bound or regulated by $p 53^{53}$ \\
\hline ECT2 & 279 & Repression requires $\mathrm{p} 107 / \mathrm{p} 130^{263}$ \\
\hline HSPA8 & 262,278 & Not bound or regulated by $p 53^{53}$ \\
\hline ID2 & 280 & Not bound or regulated by $p 53^{53}$ \\
\hline LASP1 & 281 & Not bound or regulated by $p 53^{53}$ \\
\hline MAD1L1 & 278,282 & $\begin{array}{l}\text { Not bound by } \mathrm{p} 53^{53} \\
\text { Repression requires } \mathrm{p} 21^{93,102} \\
\text { Repression requires } \mathrm{p} 107 / \mathrm{p} 130^{263}\end{array}$ \\
\hline ME1 & 80 & Not bound or regulated by $\mathrm{p} 53^{53}$ \\
\hline ME2 & 80 & Not bound or regulated by $\mathrm{p} 53^{53}$ \\
\hline ME3 & 80 & Not bound or requlated by $p 53^{53}$ \\
\hline NEK2 & 283 & $\begin{array}{l}\text { Not bound by } \mathrm{p} 53^{53} \\
\text { Repression requires } \mathrm{p} 21^{53,93}\end{array}$ \\
\hline PCNA & 284 & Activated, not repressed ${ }^{169,285}$ \\
\hline PLK1 & 286,287 & $\begin{array}{l}\text { Not bound by } \mathrm{p} 53^{107} \\
\text { Repression requires } \mathrm{p} 21^{97,107} \\
\text { Repression requires } \mathrm{p} 107 / \mathrm{p} 130^{263}\end{array}$ \\
\hline POLD1 & 288 & $\begin{array}{l}\text { Not bound by } p 53^{108} \\
\text { Repression requires } \mathrm{p} 21^{92,108}\end{array}$ \\
\hline PRC1 & 289 & $\begin{array}{l}\text { Repression requires p2193 } \\
\text { Repression requires p } 107 / \mathrm{p} 130^{263}\end{array}$ \\
\hline PTK2 (FAK) & 290 & Not bound or regulated by $p 53^{53}$ \\
\hline RAD51 & 173 & Repression requires $\mathrm{p} 21^{94}$ \\
\hline$S C D$ & 262 & Repression requires p $21^{291}$ \\
\hline TPT1 (TCTP) & 84 & Not bound or regulated by $p 53^{53}$ \\
\hline
\end{tabular}

reproducibility, ${ }^{138}$ and while some of these false findings are caused by chance, many others may be the consequences of prevailing biases. ${ }^{138}$ The survey of 319 studies on individual genes together shows that p53 target gene research still relies on the error-prone ChIP-epPCR methodology, which may promote false findings (Figure 1g). Notably, the ChIP technique in general can produce false findings. Transcription factors undergo fast turnover at non-functional binding sites that can be fixated during ChIP protocol, thereby leading to false-positive hits, ${ }^{139}$ and ChIP signals vary in general relative to formaldehyde crosslinking time. ${ }^{140,141}$ In addition, sometimes polyclonal antibody batches are used that do not contain the same antibody. To predict functional sites that lead to target gene activation, recent approaches now rely on ranking $\mathrm{p} 53$ binding sites based on multiple genome-wide data sets. $^{18,19,56}$

Here, p53 target genes are ranked by the number of data sets that report them as potential p53 target genes. The data sets include 16 genome-wide data sets and one literature-based data set, as described above (Supplementary Table S2). To be considered as high-confidence p53 target gene, a protein-coding gene was required to be identified as a p53-activated target in at least three of the 17 data sets, which ensures identification by at least two independent approaches. These criteria were met by 343 genes (Supplementary Table S3). Such an integrative approach identifies target genes that may have been missed in some data sets but have been identified in several others, and displays genes that are identified only in a small number of data sets and have a higher likelihood of being false positives.

\section{FUNCTION OF HIGH-CONFIDENCE P53 TARGET GENES}

To identify biological processes that are enriched among direct p53 target genes, a gene ontology (GO) term enrichment analysis was performed of the 343 genes that were considered as highconfidence p53 targets. As expected, GO terms associated with cell cycle arrest, apoptosis and metabolism, processes that are central to the p53 response and tumor suppression, are highly enriched for these target genes (Supplementary Table S4). Taken together, high-confidence p53 target genes function in multiple processes that include, but are not limited to, cell cycle arrest, DNA repair, apoptosis, metabolism, autophagy, translation control and feedback mechanisms (Figure 4).

\section{Cell cycle arrest}

P53 uses cell cycle checkpoints to induce G1/S $\mathrm{S}^{142,143}$ and $\mathrm{G} 2 / \mathrm{M}$ cell cycle arrest. ${ }^{144}$ CDKN1A (p21, WAF1, CIP1) was among the first p53 target genes ${ }^{11,12}$ to be identified and is now recognized as an encoder for a major cell cycle checkpoint control protein. ${ }^{145}$ Indeed, p21 is required for p53-mediated G1/S $\mathrm{S}^{146-148}$ and also for G2/M cell cycle arrest. ${ }^{149}$ P21 functions primarily by binding to and inhibiting CDKs, and in addition, p21 halts the cell cycle by blocking PCNA, which is required for DNA replication. ${ }^{150,151}$ Importantly, inhibition of CDKs leads to stabilization and activation of RB, and of the RB-related DREAM complex. As for p21, RB is also required for cell cycle arrest. ${ }^{100,152}$ Stabilization of the DREAM complex and its recruitment to target gene promoters leads to indirect p53-mediated downregulation of cell cycle genes such as $C D K 1$, Cyclin $A$ and $B, C D C 25 C$, MYBL2 (B-MYB), PLK1 and hundreds more, all of which are required for cell cycle progression. ${ }^{18,108,114}$ Taken together, p21 is sufficient to induce cell cycle arrest. ${ }^{153}$ The p53 target genes BTG $2^{36,154,155}$ and GADD45A $A^{13,156}$ can also induce G1/S and G2/M cell cycle arrest, respectively. SFN (14-3-3 sigma) encodes for a protein that removes cell cycle proteins from the nucleus and is also required for the G2/M arrest. ${ }^{51,157}$ FBXW7 ubiquitin ligase is a component of the SCF complex and mediates degradation of several cell cycle proteins, ${ }^{158}$ and its $\beta$-isoform is induced by p53. ${ }^{159}$ Notably, p53 also activates PGF, ${ }^{160}$ TGFA $^{161}$ and $K I T L G^{50}$ that encode for growth factors that can stimulate cell proliferation.

\section{DNA repair}

Given that p53 is activated in response to DNA damage, it is not surprising that several of its target genes encode for DNA repair proteins. ${ }^{162,163}$ Although the p53-mediated DNA damage response appears not to be part of p53's function as tumor suppressor, ${ }^{164}$ it does support cell viability. The p53 target genes $D D B 2^{165}$ and $X P C^{166}$ encode for proteins related to nucleotide excision repair. $R R M 2 B$ encodes for a ribonucleotide reductase that 


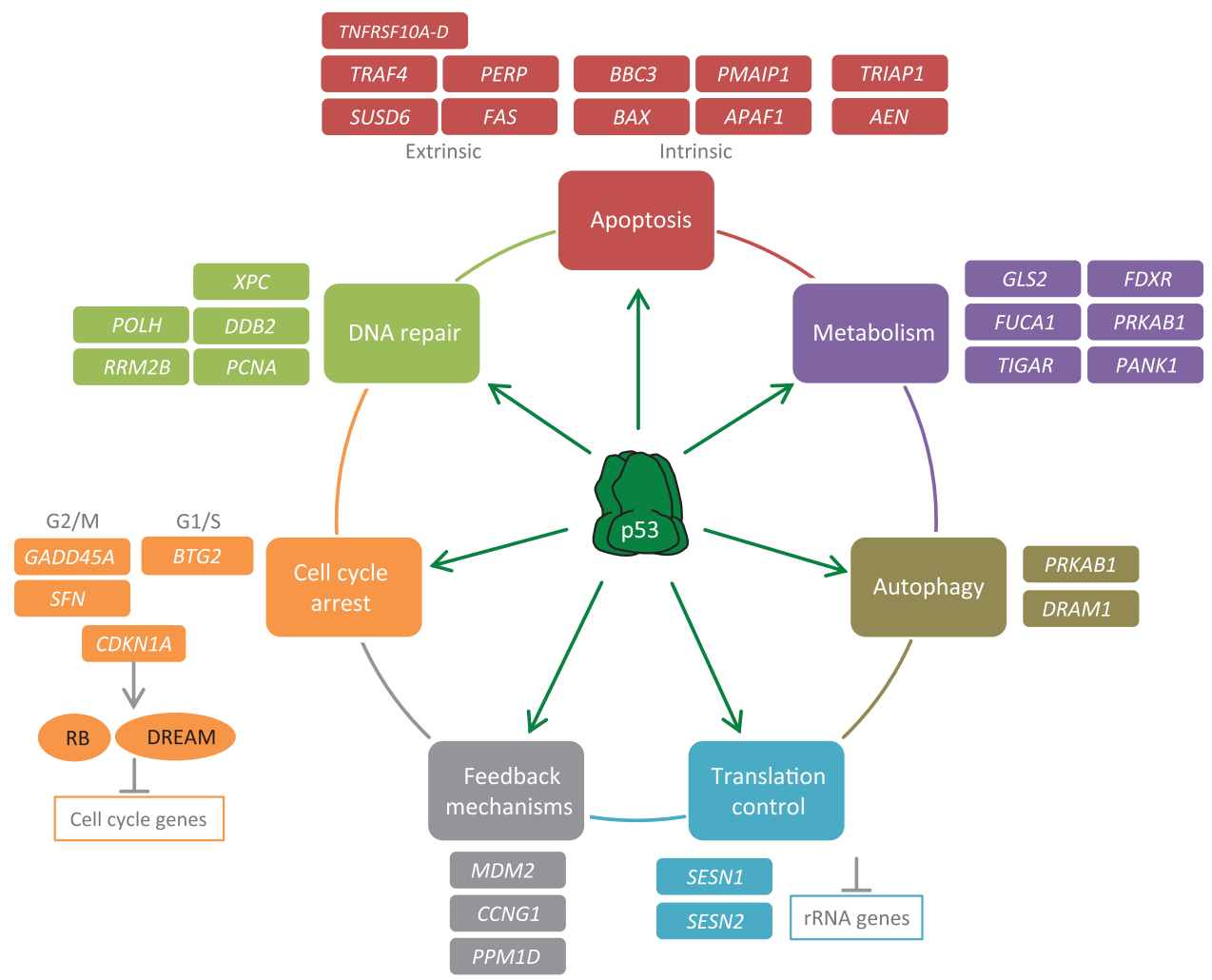

Figure 4. p53 directly activates target genes that mediate various functions. Proteins encoded by p53 target genes function in multiple processes that include, but are not limited to, cell cycle arrest, DNA repair, apoptosis, metabolism, autophagy, translation control and feedback mechanisms.

fuels DNA repair by supplying precursors, and is targeted by $\mathrm{p} 53 .{ }^{31}$ And, although PCNA is a crucial component of the replication fork during the cell cycle, it also functions in DNA repair. ${ }^{167}$ Therefore, the regulation of $P C N A$ is cell cycle-dependent, ${ }^{168}$ and is activated by $\mathrm{p} 53 .{ }^{169}$ Through the activation of $P O L H, \mathrm{p} 53$ specifically recruits a DNA polymerase that can accurately replicate damaged DNA. ${ }^{170,171}$

Many genes that encode DNA repair proteins are cell cycleregulated and are downregulated by p53 through the p53-p21DREAM pathway. Although several DNA repair genes, including $M S H 2{ }^{172}{ }^{17 D} 51^{173}$ and RECQL4, ${ }^{87}$ were thought to be direct p53 targets, it has become evident that they are indirectly repressed through the DREAM complex. ${ }^{18,108,114}$ Also, genes encoding for proteins of the Fanconi anemia DNA repair pathway are indirectly downregulated by $\mathrm{p} 53$ through p21 and DREAM. ${ }^{174}$ Interestingly, some cell cycle genes, including PCNA, POLH and AEN, are targeted by both DREAM and p53: in these cases, the transcriptional activator p53 opposes the repressive DREAM complex, leading to target gene activation. ${ }^{18}$ The DNA repair genes PMS2 and MLH1 were also believed to be p53-activated targets, ${ }^{175}$ but meta-analysis data show this unlikely to be the case $^{18}$ (Supplementary Table S2).

\section{Apoptosis}

Apoptosis, both intrinsic and extrinsic, is induced via p53 target genes. ${ }^{176,177}$ The extrinsic apoptosis signaling pathway is largely controlled by the tumor necrosis factor (TNF) receptor family. TNF receptors include the p53-induced targets $F A S^{47-49}$ and TNFRSF10A-D ${ }^{38,39}$ these can be activated by external stimuli such as binding with FASL or TNF-a, thereby leading to caspase-dependent apoptosis. ${ }^{178}$ The gene that encodes for the TNF receptor-associated protein 4 (TRAF4) is also a p53 target. ${ }^{179}$ Additional apoptosis-inducing transmembrane proteins are encoded by the $\mathrm{p} 53$ targets PERP ${ }^{180}$ and SUSD6 (TMPS; KIAA0247). ${ }^{33}$ On the other hand, the intrinsic apoptosis pathway is regulated by the $\mathrm{BCL}-2$ family of proteins, which control the release of cytochrome $c$ from the mitochondria. Several proapoptotic BCL-2 family members, including $B A X^{41-43} B B C 3(P \cup M A)^{181}$ and PMAIP1 (NOXA), ${ }^{182}$ are activated by $\mathrm{p} 53$. When released from the mitochondria, cytochrome $c$ binds to APAF1 and procaspase 9 to form the apoptosome. APAF1 is activated by p53 too. ${ }^{183-185}$ The p53 target gene $A E N$ encodes for an apoptosis-enhancing nuclease that further supports apoptosis through digestion of double-stranded DNA. ${ }^{4}$ Apoptosis also can be activated by ceramide, ${ }^{186}$ and p53 appears to directly upregulate the ceramide synthase-encoding genes CERS5 (Table 1) and CERS6 ${ }^{187}$ and to induce ceramide production. ${ }^{188}$ Although many p53 target genes encode for apoptosis-promoting proteins, the p53 target TRIAP1 encodes for an inhibitor of apoptosis. ${ }^{189}$ Additional BCL-2 family members reported as p53 targets include $B C L 2^{190,191}$ and $B I D^{192}-$ but these are not directly regulated by p53 according to meta-analysis data $^{18}$ (Supplementary Table S2). AIFM1 (AIF; apoptosis-inducing factor), also proposed as a p53 target, $^{193}$ appears not to be regulated by $\mathrm{p} 53$.

\section{Metabolism}

Target genes directly regulated by $\mathrm{p} 53$ participate in multiple metabolic pathways. ${ }^{194,195}$ The TP53-induced glycolysis and apoptosis regulator, encoded by p53 target gene TIGAR (C12orf5), functions in glycolysis by degrading fructose-2,6bisphosphate, and thereby opposing the Warburg effect. ${ }^{37}$ The carbohydrate fucose is degraded through a fucosidase that is encoded by the p53 target FUCA1. ${ }^{196}$ GLS2 catalyzes the hydrolysis of glutamine to glutamate and ammonia and is encoded by a direct p53 target gene. ${ }^{197,198}$ PANK1 is a p53 target, which encodes for a key regulatory enzyme in the biosynthesis of 
coenzyme A. ${ }^{199,200}$ PRKAB1 is also targeted by $\mathrm{p} 53$ and encodes for AMP-activated protein kinase beta- 1 subunit, which is involved in phosphorylation and inactivation of acetyl-coenzyme A carboxylase and $\beta$-hydroxy $\beta$-methylglutaryl-coenzyme $A$ reductase, key enzymes involved in regulating de novo biosynthesis of fatty acids and cholesterol. ${ }^{201}$ The $\mathrm{p} 53$ target FDXR encodes a mitochondrial flavoprotein that initiates electron transport for cytochromes P450, which receive electrons from $\mathrm{NADPH}{ }^{202}$

Several additional genes, including SCO2, ${ }^{203}$ PARK2 (Parkin), ${ }^{133}$ LPIN1, ${ }^{204}$ CPT1C, ${ }^{205}$ SLC2A3 (GLUT3), ${ }^{206}$ SLC2A4 (GLUT4) ${ }^{207}$ and ME1, $M E 2$ and $M E 3^{80}$ are involved in metabolism and are believed to be directly regulated by $\mathrm{p} 53$. However, according to meta-analysis data these genes are not regulated by p53 in humans ${ }^{18}$ (Supplementary Table S2).

\section{Autophagy}

Autophagy is another cellular program that is triggered by cell stress and p53. ${ }^{195,208}$ The p53 target gene DRAM1 encodes a lysosomal membrane protein that is required for the induction of autophagy by p53. ${ }^{209}$ AMPK, which p53 activates by direct activation of $P R K A B 1$, blocks the mammalian target of rapamycin (mTOR) pathway, and leads to autophagy. ${ }^{201,210}$ P53 can further block mTOR activity through its direct target genes SESN1 and SESN2. ${ }^{211}$ And, although ULK1 and ULK2, which encode autophagy-activating kinases, were thought to be regulated by $\mathrm{p} 53,^{137}$ their regulation by $\mathrm{p} 53$ is not supported by meta-analysis data $^{18}$ (Supplementary Table S2).

\section{Translation control}

Protein biosynthesis and mRNA translation are both influenced by p53. When cells undergo stress and p53 becomes active, mRNA translation and protein biosynthesis is repressed, to inhibit cell growth. Induction of p53 leads to downregulation of rRNA genes ${ }^{212,213}$ and of genes that are required for import and export of ribosomal proteins from the nucleus. ${ }^{214}$ In addition, p53 uses two direct target genes, SESN1 and SESN2, to block mTOR and to repress mRNA translation. ${ }^{211,215}$

Feedback regulation

Through activation of its target genes, p53 activates several feedback loops, both positive and negative. ${ }^{216}$ The best known feedback loop uses MDM2, a p53 target gene that encodes a ubiquitin ligase, which mediates degradation of $\mathrm{p53} .^{14,15,217}$ MDM2 function is supported through cyclin G1, which activates MDM2 through dephosphorylation ${ }^{218}$ and CCNG1 is a p53 target itself. ${ }^{219}$ PPM1D (WIP1) is also a p53 target and encodes for a phosphatase that confers a negative feedback loop through p53 dephosphorylation and cell cycle checkpoint abrogation. ${ }^{40,220,221}$ Members of the TRIM protein family, such as PML (TRIM19) ${ }^{222}$ and TRIM22, ${ }^{223}$ are transcriptionally activated by p53 and have been shown to alter the p53 response. ${ }^{24}$

Through p21, p53 is engaged in additional feedback loops. CDK inhibition by $\mathrm{p} 21$ leads to the activation of RB and suppression of activating E2Fs. E2F1 signals positive and negative feedback to p53. ${ }^{225}$ E2F1 can induce ARF, which blocks MDM2-mediated p53 degradation, ${ }^{226}$ and it can also induce SIRT1, which impairs p53 function through deacetylation. ${ }^{227}$

Additional genes believed to be involved in feedback loops as p53 targets include SIAH1, 228 RCHY1 (Pirh2) ${ }^{229}$ and RFWD2 $(C O P 1){ }^{230}$ but these are not regulated by $\mathrm{p} 53$ according to meta-analysis data ${ }^{18}$ (Supplementary Table S2).

\section{OUTLOOK}

For a number of decades, the study of p53 led to increasingly complex models of its function: 'If genius is the ability to reduce the complicated to the simple, then the study of p53 makes fools of us all'. ${ }^{231}$ However, recent meta-analysis approaches that enabled comparisons of multiple genome-wide data sets of p53 binding and gene regulation, have started to simplify our understanding of p53 function:

- The transcription factor p53 itself is solely an activator of transcription. ${ }^{53,232}$

- Gene downregulation by p53 is indirect and requires p21. ${ }^{18,116}$

- Functional p53 binding sites are independent of cell type and treatment. $^{19}$

- Most functional p53 binding sites are found in proximal promoters $^{18}$ (Figure 1e).

- Functional p53 binding sites consist of two decameric half-sites, and likely do not contain spacers in between. ${ }^{19,56}$

- Noncanonical binding sites, including half-sites, appear to be non-functional. ${ }^{19}$

- P53 mostly acts alone to activate target genes, and does not depend on cofactors binding to the same promoter. ${ }^{19}$

- The number of true p53 target genes is limited, and likely does not exceed a few hundred ${ }^{18}$ (Figure $2 a$ and Supplementary Tables S2 and S3).

Given recent advances in our understanding of p53 function, one can envision that genome-wide data integration approaches will answer additional questions and clarify further obscurities.

\section{CONFLICT OF INTEREST}

The author declares no conflict of interest.

\section{ACKNOWLEDGEMENTS}

I thank Dr Sonal Jhaveri, in the Postdoctoral and Graduate Student Affairs office at the Dana-Farber Cancer Institute, for help with editing a draft of the manuscript. I am especially grateful to Dr Kurt Engeland and Dr James A DeCaprio for their inspiring mentorship. My research is supported through a Junior Researcher Grant by the Medical School, University of Leipzig and an Add-On Fellowship for Interdisciplinary Science in Systems Biology by the Joachim Herz Stiftung.

\section{REFERENCES}

1 Vogelstein B, Lane D, Levine AJ. Surfing the p53 network. Nature 2000; 408: 307-310.

2 Levine AJ, Oren M. The first 30 years of p53: growing ever more complex. Nat Rev Cancer 2009; 9: 749-758.

3 Lawrence MS, Stojanov P, Mermel CH, Robinson JT, Garraway La, Golub TR et al. Discovery and saturation analysis of cancer genes across 21 tumour types. Nature 2014; 505: 495-501.

4 Horn HF, Vousden KH. Coping with stress: multiple ways to activate p53. Oncogene 2007; 26: 1306-1316.

5 Riley T, Sontag E, Chen P, Levine A. Transcriptional control of human p53regulated genes. Nat Rev Mol Cell Biol 2008; 9: 402-412.

6 Beckerman R, Prives C. Transcriptional regulation by p53. Cold Spring Harb Perspect Biol 2010; 2: a000935.

7 El-Deiry WS, Kern SE, Pietenpol JA, Kinzler KW, Vogelstein B. Definition of a consensus binding site for p53. Nat Genet 1992; 1: 45-49.

8 McLure KG, Lee PWK. How p53 binds DNA as a tetramer. EMBO J 1998; 17: 3342-3350.

9 Kitayner M, Rozenberg H, Kessler N, Rabinovich D, Shaulov L, Haran TE et al. Structural basis of DNA recognition by p53 tetramers. Mol Cell 2006; 22: 741-753.

10 Veprintsev DB, Freund SMV, Andreeva A, Rutledge SE, Tidow H, Cañadillas JMP et al. Core domain interactions in full-length p53 in solution. Proc Natl Acad Sci USA 2006; 103: 2115-2119.

11 El-Deiry WS, Tokino T, Velculescu VE, Levy DB, Parsons R, Trent JM et al. WAF1, a potential mediator of p53 tumor suppression. Cell 1993; 75: 817-825.

12 El-Deiry WS, Tokino T, Waldman T, Oliner JD, Velculescu VE, Burrell M et al. Topological control of p21WAF1/CIP1 expression in normal and neoplastic tissues. Cancer Res 1995; 55: 2910-2919. 
13 Kastan MB, Zhan Q, El-Deiry WS, Carrier F, Jacks T, Walsh WV et al. A mammalian cell cycle checkpoint pathway utilizing p53 and GADD45 is defective in ataxia-telangiectasia. Cell 1992; 71: 587-597.

$14 \mathrm{Wu} \mathrm{XW}$, Bayle JH, Olson D, Levine AJ. The P53 Mdm-2 autoregulatory feedback loop. Genes Dev 1993; 7: 1126-1132.

15 Juven T, Barak Y, Zauberman A, George DL, Oren M. Wild type p53 can mediate sequence-specific transactivation of an internal promoter within the $\mathrm{mdm} 2$ gene. Oncogene 1993; 8: 3411-3416.

16 Wei $\mathrm{CL}$, Wu Q, Vega VB, Chiu KP, Ng P, Zhang T et al. A global map of p53 transcription-factor binding sites in the human genome. Cell 2006; 124: 207-219.

17 Li M, He Y, Dubois W, Wu X, Shi J, Huang J. Distinct regulatory mechanisms and functions for p53-activated and p53-repressed DNA damage response genes in embryonic stem cells. Mol Cell 2012; 46: 30-42.

18 Fischer M, Grossmann P, Padi M, DeCaprio JA. Integration of TP53, DREAM, MMBFOXM1 and RB-E2F target gene analyses identifies cell cycle gene regulatory networks. Nucleic Acids Res 2016; 44: 6070-6086.

19 Verfaillie A, Svetlichnyy D, Imrichova H, Davie K, Fiers M, Atak ZK et al. Multiplex enhancer-reporter assays uncover unsophisticated TP53 enhancer logic. Genome Res 2016; 26: 882-895.

20 Smeenk L, van Heeringen SJ, Koeppel M, Gilbert B, Janssen-Megens E, Stunnenberg $\mathrm{HG}$ et al. Role of p53 serine 46 in p53 target gene regulation. PLoS One 2011; 6: e17574.

21 Nikulenkov F, Spinnler C, Li H, Tonelli C, Shi Y, Turunen M et al. Insights into p53 transcriptional function via genome-wide chromatin occupancy and gene expression analysis. Cell Death Differ 2012; 19: 1992-2002.

22 Menendez D, Nguyen TA, Freudenberg JM, Mathew VJ, Anderson CW, Jothi R et al. Diverse stresses dramatically alter genome-wide p53 binding and transactivation landscape in human cancer cells. Nucleic Acids Res 2013; 41: 7286-7301.

23 Schlereth K, Heyl C, Krampitz AM, Mernberger M, Finkernagel F, Scharfe M et al. Characterization of the p53 cistrome-DNA binding cooperativity dissects p53's tumor suppressor functions. PLoS Genet 2013; 9: e1003726.

24 Allen MA, Andrysik Z, Dengler VL, Mellert HS, Guarnieri A, Freeman JA et al. Global analysis of p53-regulated transcription identifies its direct targets and unexpected regulatory mechanisms. Elife 2014; 3: e02200.

25 Janky R, Verfaillie A, Imrichová H, van de Sande B, Standaert L, Christiaens V et al. iRegulon: from a gene list to a gene regulatory network using large motif and track collections. PLoS Comput Biol 2014; 10: e1003731.

26 McDade SS, Patel D, Moran M, Campbell J, Fenwick K, Kozarewa I et al. Genomewide characterization reveals complex interplay between TP53 and TP63 in response to genotoxic stress. Nucleic Acids Res 2014; 42: 6270-6285.

27 Chang GS, Chen XA, Park B, Rhee HS, Li P, Han KH et al. A Comprehensive and high-resolution genome-wide response of p53 to stress. Cell Rep 2014; 8 514-527.

28 Rashi-Elkeles S, Warnatz H-J, Elkon R, Kupershtein A, Chobod Y, Paz A et al. Parallel profiling of the transcriptome, cistrome, and epigenome in the cellular response to ionizing radiation. Sci Signal 2014; 7: 1-11.

29 Wang B, Niu D, Lam TH, Xiao Z, Ren EC. Mapping the p53 transcriptome universe using p53 natural polymorphs. Cell Death Differ 2014; 21: 521-532.

30 Younger ST, Kenzelmann-Broz D, Jung H, Attardi LD, Rinn JL. Integrative genomic analysis reveals widespread enhancer regulation by $\mathrm{p} 53$ in response to DNA damage. Nucleic Acids Res 2015; 43: 4447-4462.

31 Tanaka H, Arakawa H, Yamaguchi T, Shiraishi K, Fukuda S, Matsui K et al. A ribonucleotide reductase gene involved in a p53-dependent cell-cycle checkpoint for DNA damage. Nature 2000; 404: 42-49.

32 Tan M, Wang Y, Guan K, Sun Y. PTGF-beta, a type beta transforming growth factor (TGF-beta) superfamily member, is a p53 target gene that inhibits tumor cell growth via TGF-beta signaling pathway. Proc Natl Acad Sci USA 2000; 97: 109-114

33 Cui H, Kamino H, Nakamura Y, Kitamura N, Miyamoto T, Shinogi D et al. Regulation of apoptosis by p53-inducible transmembrane protein containing sushi domain. Oncol Rep 2010; 24: 1193-1200.

34 Polato F, Rusconi P, Zangrossi S, Morelli F, Boeri M, Musi A et al. DRAGO (KIAA0247), a new DNA damage-responsive, p53-inducible gene that cooperates with p53 as oncosupprossor. J Nat/ Cancer Inst 2014; 106: dju053.

35 Jen K-Y, Cheung VG. Identification of novel p53 target genes in ionizing radiation response. Cancer Res 2005; 65: 7666-7673.

36 Duriez C, Falette N, Audoynaud C, Moyret-Lalle C, Bensaad K, Courtois S et al. The human BTG2/TIS21/PC3 gene: genomic structure, transcriptional regulation and evaluation as a candidate tumor suppressor gene. Gene 2002; 282: 207-214.

37 Bensaad K, Tsuruta A, Selak MA, Vidal MNC, Nakano K, Bartrons R et al. TIGAR, a p53-inducible regulator of glycolysis and apoptosis. Cell 2006; 126: 107-120.

38 Takimoto R, El-Deiry WS. Wild-type p53 transactivates the KILLER/DR5 gene through an intronic sequence-specific DNA-binding site. Oncogene 2000; 19: 1735-1743.
39 Liu X, Yue P, Khuri FR, Sun SY. p53 upregulates death receptor 4 expression through an intronic p53 binding site. Cancer Res 2004; 64: 5078-5083.

40 Rossi M, Demidov ON, Anderson CW, Appella E, Mazur SJ. Induction of PPM1D following DNA-damaging treatments through a conserved p53 response element coincides with a shift in the use of transcription initiation sites. Nucleic Acids Res 2008; 36: 7168-7180.

41 Toshiyuki M, Reed J. Tumor suppressor p53 is a direct transcriptional activator of the human bax gene. Cell 1995; 80: 293-299.

42 Pierzchalski P, Reiss K, Cheng W, Cirielli C, Kajstura J, Nitahara JA et al. p53 induces myocyte apoptosis via the activation of the renin-angiotensin system. Exp Cell Res 1997; 234: 57-65.

43 Thornborrow EC, Patel S, Mastropietro AE, Schwartzfarb EM, Manfredi JJ. A conserved intronic response element mediates direct p53-dependent transcriptional activation of both the human and murine bax genes. Oncogene 2002; 21: 990-999.

44 Kawase T, Ichikawa H, Ohta T, Nozaki N, Tashiro F, Ohki R et al. p53 target gene $\mathrm{AEN}$ is a nuclear exonuclease required for p53-dependent apoptosis. Oncogene 2008; 27: 3797-3810.

45 Burns TF, Fei P, Scata KA, Dicker DT, El-Deiry WS. Silencing of the novel p53 target gene Snk/Plk2 leads to mitotic catastrophe in paclitaxel (Taxol)exposed cells. Mol Cell Biol 2003; 23: 5556-5571.

46 Velasco-Miguel S, Buckbinder L, Jean P, Gelbert L, Talbott R, Laidlaw J et al. PA26, a novel target of the p53 tumor suppressor and member of the GADD family of DNA damage and growth arrest inducible genes. Oncogene 1999; 18: 127-137.

47 Müller M, Wilder S, Bannasch D, Israeli D, Lehlbach K, Li-Weber M et al. p53 activates the CD95 (APO-1/Fas) gene in response to DNA damage by anticancer drugs. J Exp Med 1998; 188: 2033-2045.

48 Munsch D, Watanabe-Fukunaga R, Bourdon JC, Nagata S, May E, Yonish-Rouach E et al. Human and mouse Fas (APO-1/CD95) death receptor genes each contain a p53-responsive element that is activated by p53 mutants unable to induce apoptosis. J Biol Chem 2000; 275: 3867-3872.

49 Schilling T, Schleithoff ES, Kairat A, Melino G, Stremmel W, Oren M et al. Active transcription of the human FAS/CD95/TNFRSF6 gene involves the p53 family. Biochem Biophys Res Commun 2009; 387: 399-404.

50 Zeron-Medina J, Wang X, Repapi E, Campbell MR, Su D, Castro-Giner F et al. A polymorphic p53 response element in KIT ligand influences cancer risk and has undergone natural selection. Cell 2013; 155: 410-422.

51 Hermeking $\mathrm{H}$, Lengauer $\mathrm{C}$, Polyak $\mathrm{K}$, He T-C, Zhang $\mathrm{L}$, Thiagalingam $\mathrm{S}$ et al. $14-3-3 \sigma$ Is a p53-regulated inhibitor of G2/M progression. Mol Cell 1997; 1: $3-11$.

52 Budanov AV, Shoshani T, Faerman A, Zelin E, Kamer I, Kalinski H et al. Identification of a novel stress-responsive gene Hi95 involved in regulation of cell viability. Oncogene 2002; 21: 6017-6031.

53 Fischer M, Steiner L, Engeland K. The transcription factor p53: not a repressor solely an activator. Cell Cycle 2014; 13: 3037-3058.

54 Jordan JJ, Menendez D, Inga A, Nourredine M, Bell D, Resnick MA. Noncanonical DNA motifs as transactivation targets by wild type and mutant p53. PLoS Genet 2008; 4: e1000104.

55 Menendez D, Inga A, Resnick MA. The expanding universe of p53 targets. Nat Rev Cancer 2009; 9: 724-737.

56 Tebaldi T, Zaccara S, Alessandrini F, Bisio A, Ciribilli $Y$, Inga A et al. Wholegenome cartography of $\mathrm{p} 53$ response elements ranked on transactivation potential. BMC Genomics 2015; 16: 464

57 Batchelor E, Mock CS, Bhan I, Loewer A, Lahav G. Recurrent initiation: a mechanism for triggering p53 pulses in response to DNA damage. Mol Cell 2008; 30: 277-289.

58 Brady CA, Jiang D, Mello SS, Johnson TM, Jarvis LA, Kozak MM et al. Distinct p53 transcriptional programs dictate acute DNA-damage responses and tumor suppression. Cell 2011; 145: 571-583.

59 Schlereth K, Beinoraviciute-Kellner R, Zeitlinger MK, Bretz AC, Sauer M, Charles JP et al. DNA binding cooperativity of p53 modulates the decision between cellcycle arrest and apoptosis. Mol Cell 2010; 38: 356-368.

60 Espinosa JM, Verdun RE, Emerson BM. p53 functions through stress- and promoter-specific recruitment of transcription initiation components before and after DNA damage. Mol Cell 2003; 12: 1015-1027.

61 Morachis JM, Murawsky CM, Emerson BM. Regulation of the p53 transcriptional response by structurally diverse core promoters. Genes Dev 2010; 24: 135-147.

62 Lauberth SM, Nakayama T, Wu X, Ferris AL, Tang Z, Hughes SH et al. H3K4me3 interactions with TAF3 regulate preinitiation complex assembly and selective gene activation. Cell 2013; 152: 1021-1036.

63 Purvis JE, Karhohs KW, Mock C, Batchelor E, Loewer A, Lahav G. p53 Dynamics Control Cell Fate. Science 2012; 336: 1440-1444. 
64 Carninci P, Sandelin A, Lenhard B, Katayama S, Shimokawa K, Ponjavic J et al. Genome-wide analysis of mammalian promoter architecture and evolution. Nat Genet 2006; 38: 626-635.

65 Melo CA, Drost J, Wijchers PJ, van de Werken $\mathrm{H}$, de Wit E, Vrielink JAFO et al. ERNAs are required for p53-dependent enhancer activity and gene transcription. Mol Cell 2013; 49: 524-535.

66 Léveillé N, Melo CA, Rooijers K, Díaz-Lagares A, Melo SA, Korkmaz G et al. Genome-wide profiling of p53-regulated enhancer RNAs uncovers a subset of enhancers controlled by a IncRNA. Nat Commun 2015; 6: 6520.

67 Barak Y, Gottlieb E, Juven-Gershon T, Oren M. Regulation of mdm2 expression by p53: alternative promoters produce transcripts with nonidentical translation potential. Genes Dev 1994; 8: 1739-1749.

68 Zauberman A, Flusberg D, Haupt Y, Barak Y, Oren M. A functional p53-responsive intronic promoter is contained within the human mdm2 gene. Nucleic Acids Res 1995; 23: 2584-2592.

$69 \mathrm{Ho}$ J, Benchimol S. Transcriptional repression mediated by the p53 tumour suppressor. Cell Death Differ 2003; 10: 404-408.

70 Wang B, Xiao Z, Ko HL, Ren EC. The p53 response element and transcriptional repression. Cell Cycle 2010; 9: 870-879.

71 Rinn JL, Huarte M. To repress or not to repress: this is the guardian's question. Trends Cell Biol 2011; 21: 344-353.

72 Böhlig L, Rother K. One function-multiple mechanisms: the manifold activities of p53 as a transcriptional repressor. J Biomed Biotechnol 2011; 2011: 464916.

73 Mack DH, Vartikar J, Pipas JM, Laimins L. Specific repression of TATA-mediated but not initiator-mediated transcription by wild-type p53. Nature 1993; 363: 281-283.

74 Ragimov N, Krauskopf A, Navot N, Rotter V, Oren M, Aloni Y. Wild-type but not mutant $\mathrm{p} 53$ can repress transcription initiation in vitro by interfering with the binding of basal transcription factors to the TATA motif. Oncogene 1993; 8: 1183-1193.

75 Agoff SN, Hou J, Linzer DI, Wu B. Regulation of the human hsp70 promoter by p53. Science 1993; 259: 84-87.

76 Borellini F, Glazer RI. Induction of Sp1-p53 DNA-binding heterocomplexes during granulocyte/macrophage colony-stimulating factor-dependent proliferation in human erythroleukemia cell line TF-1. J Biol Chem 1993; 268: 7923-7928.

77 Imbriano C, Gnesutta N, Mantovani R. The NF-Y/p53 liaison: well beyond repression. Biochim Biophys Acta 2012; 1825: 131-139.

78 Zhang L, Yu D, Hu M, Xiong S, Lang A, Ellis LM et al. Wild-type p53 suppresses angiogenesis in human leiomyosarcoma and synovial sarcoma by transcriptional suppression of vascular endothelial growth factor expression. Cancer Res 2000; 60: 3655-3661.

79 Tschaharganeh DF, Xue W, Calvisi DF, Evert M, Michurina TV, Dow LE et al. p53-dependent nestin regulation links tumor suppression to cellular plasticity in liver cancer. Cell 2014; 158: 579-592.

80 Jiang $\mathrm{P}$, Du W, Mancuso A, Wellen KE, Yang X. Reciprocal regulation of p53 and malic enzymes modulates metabolism and senescence. Nature 2013; 493: 689-693.

81 Jiang L, Kon N, Li T, Wang SJ, Su T, Hibshoosh $\mathrm{H}$ et al. Ferroptosis as a p53-mediated activity during tumour suppression. Nature 2015; 520: 57-62.

82 Johnson RA, Ince TA, Scotto KW. Transcriptional repression by p53 through direct binding to a novel DNA element. J Biol Chem 2001; 276: 27716-27720.

83 Godar S, Ince TA, Bell GW, Feldser D, Donaher JL, Bergh J et al. Growth-inhibitory and tumor-suppressive functions of p53 depend on its repression of CD44 expression. Cell 2008; 134: 62-73.

84 Amson R, Pece S, Lespagnol A, Vyas R, Mazzarol G, Tosoni D et al. Reciprocal repression between P53 and TCTP. Nat Med 2011; 18: 91-99.

85 Wang B, Xiao Z, Ren EC. Redefining the p53 response element. Proc Natl Acad Sci USA 2009; 106: 14373-14378.

86 Imbriano C, Gurtner A, Cocchiarella F, Di Agostino S, Basile V, Gostissa M et al. Direct p53 transcriptional repression: in vivo analysis of CCAAT-containing G2/M promoters. Mol Cell Biol 2005; 25: 3737-3751.

87 Sengupta S, Shimamoto A, Koshiji M, Pedeux R, Rusin M, Spillare EA et al. Tumor suppressor p53 represses transcription of RECQ4 helicase. Oncogene 2005; 24: 1738-1748.

88 Li H, Zhang Y, Ströse A, Tedesco D, Gurova K, Selivanova G. Integrated highthroughput analysis identifies Sp1 as a crucial determinant of p53-mediated apoptosis. Cell Death Differ 2014; 21: 1493-1502.

89 Kenzelmann Broz D, Mello SS, Bieging KT, Jiang D, Dusek RL, Brady CA et al. Global genomic profiling reveals an extensive p53-regulated autophagy program contributing to key p53 responses. Genes Dev 2013; 27: 1016-1031.

90 Azzam El, deToledo SM, Pykett MJ, Nagasawa H, Little JB. CDC2 is downregulated by ionizing radiation in a p53-dependent manner. Cell Growth Differ 1997; 8: 1161-1169.
91 Spitkovsky D, Schulze A, Boye B, Jansen-Dürr P. Down-regulation of cyclin A gene expression upon genotoxic stress correlates with reduced binding of free E2F to the promoter. Cell Growth Differ 1997; 8: 699-710.

92 Löhr K, Mo C, Contente A, Dobbelstein M. p21/CDKN1A mediates negative regulation of transcription by p53. J Biol Chem 2003; 278: 32507-32516.

93 Tabach Y, Milyavsky M, Shats I, Brosh R, Zuk O, Yitzhaky A et al. The promoters of human cell cycle genes integrate signals from two tumor suppressive pathways during cellular transformation. Mol Syst Biol 2005; 1: 2005.0022.

94 de Toledo SM, Azzam El, Keng P, Laffrenier S, Little JB. Regulation by ionizing radiation of $C D C 2$, cyclin $A$, cyclin $B$, thymidine kinase, topoisomerase llalpha, and RAD51 expression in normal human diploid fibroblasts is dependent on p53/p21Waf1. Cell Growth Differ 1998; 9: 887-896.

95 Scian MJ, Carchman EH, Mohanraj L, Stagliano KER, Anderson MaE, Deb D et al. Wild-type p53 and p73 negatively regulate expression of proliferation related genes. Oncogene 2008; 27: 2583-2593.

96 Kidokoro T, Tanikawa C, Furukawa Y, Katagiri T, Nakamura Y, Matsuda K. CDC20, a potential cancer therapeutic target, is negatively regulated by $\mathrm{p} 53$. Oncogene 2008; 27: 1562-1571.

97 Zhu H, Chang BD, Uchiumi T, Roninson IB. Identification of promoter elements responsible for transcriptional inhibition of polo-like kinase 1 and topoisomerase Ilalpha genes by p21(WAF1/CIP1/SDI1). Cell Cycle 2002; 1: 59-66.

98 Taylor WR, Schönthal AH, Galante J, Stark GR. P130/E2F4 binds to and represses the cdc2 promoter in response to p53. J Biol Chem 2001; 276: 1998-2006.

99 Shats I, Milyavsky M, Tang X, Stambolsky P, Erez N, Brosh R et al. p53-dependent down-regulation of telomerase is mediated by P21 Waf1. J Biol Chem 2004; 279: 50976-50985.

100 Flatt PM, Tang LJ, Scatena CD, Szak ST, Pietenpol JA. p53 regulation of G(2) checkpoint is retinoblastoma protein dependent. Mol Cell Biol 2000; 20: 4210-4223.

101 Jackson JG, Pereira-Smith OM. Primary and compensatory roles for RB family members at cell cycle gene promoters that are deacetylated and downregulated in doxorubicin-induced senescence of breast cancer cells. Mol Cell Biol 2006; 26: 2501-2510.

102 Schvartzman JM, Duijf PHG, Sotillo R, Coker C, Benezra R. Mad2 is a critical mediator of the chromosome instability observed upon Rb and p53 pathway inhibition. Cancer Cell 2011; 19: 701-714.

103 Gottifredi V, Karni-schmidt O, Shieh S, Prives C. p53 down-regulates CHK1 through p21 and the retinoblastoma protein. Mol Cell Biol 2001; 21: 1066-1076.

104 Litovchick L, Sadasivam S, Florens L, Zhu X, Swanson SK, Velmurugan S et al. Evolutionarily conserved multisubunit RBL2/p130 and E2F4 protein complex represses human cell cycle-dependent genes in quiescence. Mol Cell 2007; 26: 539-551.

105 Schmit F, Korenjak M, Mannefeld M, Schmitt K, Franke C, Von Eyss B et al. LINC, a human complex that is related to pRB-containing complexes in invertebrates regulates the expression of G2/M genes. Cell Cycle 2007; 6: 1903-1913.

106 Sadasivam S, DeCaprio JA. The DREAM complex: master coordinator of cell cycledependent gene expression. Nat Rev Cancer 2013; 13: 585-595.

107 Mannefeld M, Klassen E, Gaubatz S. B-MYB is required for recovery from the DNA damage-induced G2 checkpoint in p53 mutant cells. Cancer Res 2009; 69: 4073-4080.

108 Calvisi DF, Simile MM, Ladu S, Frau M, Evert M, Tomasi ML et al. Activation of v-Myb avian myeloblastosis viral oncogene homolog-like2 (MYBL2)-LIN9 complex contributes to human hepatocarcinogenesis and identifies a subset of hepatocellular carcinoma with mutant p53. Hepatology 2011; 53: 1226-1236.

109 Quaas M, Müller GA, Engeland K. p53 can repress transcription of cell cycle genes through a p21 WAF1/CIP1-dependent switch from MMB to DREAM protein complex binding at CHR promoter elements. Cell Cycle 2012; 11: 4661-4672.

110 Fischer M, Grundke I, Sohr S, Quaas M, Hoffmann S, Knörck A et al. p53 and cell cycle dependent transcription of kinesin family member 23 (KIF23) is controlled via a CHR promoter element bound by DREAM and MMB complexes. PLoS One 2013; 8: e63187.

111 Fischer M, Quaas M, Wintsche A, Müller GA, Engeland K. Polo-like kinase 4 transcription is activated via CRE and NRF1 elements, repressed by DREAM through CDE/CHR sites and deregulated by HPV E7 protein. Nucleic Acids Res 2014; 42: 163-180.

112 Fischer M, Quaas M, Nickel A, Engeland K. Indirect p53-dependent transcriptional repression of Survivin, $C D C 25 C$, and PLK1 genes requires the cyclindependent kinase inhibitor p21/CDKN1A and CDE/CHR promoter sites binding the DREAM complex. Oncotarget 2015; 6: 41402-41417.

113 Fischer M, Quaas M, Steiner L, Engeland K. The p53-p21-DREAM-CDE/CHR pathway regulates G2/M cell cycle genes. Nucleic Acids Res 2016; 44: 164-174. 
114 Müller GA, Stangner K, Schmitt T, Wintsche A, Engeland K. Timing of transcription during the cell cycle: protein complexes binding to $\mathrm{E} 2 \mathrm{~F}, \mathrm{E} 2 \mathrm{~F} / \mathrm{CLE}, \mathrm{CDE} / \mathrm{CHR}$, or $\mathrm{CHR}$ promoter elements define early and late cell cycle gene expression. Oncotarget 2016; e-pub ahead of print 28 July 2016; doi:10.18632/oncotarget.10888.

115 Spurgers KB, Gold DL, Coombes KR, Bohnenstiehl NL, Mullins B, Meyn RE et al. Identification of cell cycle regulatory genes as principal targets of p53-mediated transcriptional repression. J Biol Chem 2006; 281: 25134-25142.

116 Fischer M. P21 governs p53's repressive side. Cell Cycle 2016; 15: 2852-2853.

117 Carvajal LA, Hamard PJ, Tonnessen C, Manfredi JJ. E2F7, a novel target, is upregulated by $\mathrm{p} 53$ and mediates DNA damage-dependent transcriptional repression. Genes Dev 2012; 26: 1533-1545.

118 Westendorp B, Mokry M, Groot Koerkamp MJA, Holstege FCP, Cuppen E, De Bruin A. E2F7 represses a network of oscillating cell cycle genes to control S-phase progression. Nucleic Acids Res 2012; 40: 3511-3523.

119 Benson EK, Mungamuri SK, Attie O, Kracikova M, Sachidanandam R, Manfredi J et al. p53-dependent gene repression through p21 is mediated by recruitment of E2F4 repression complexes. Oncogene 2014; 33: 3959-3969.

120 Hermeking $\mathrm{H}$. MicroRNAs in the p53 network: micromanagement of tumour suppression. Nat Rev Cancer 2012; 12: 613-626.

121 Grossi E, Sánchez Y, Huarte M. Expanding the p53 regulatory network: LncRNAs take up the challenge. Biochim Biophys Acta 2016; 1859: 200-208.

122 Khalil AM, Guttman M, Huarte M, Garber M, Raj A, Rivea Morales D et al. Many human large intergenic noncoding RNAs associate with chromatin-modifying complexes and affect gene expression. Proc Natl Acad Sci USA 2009; 106: 11667-11672.

123 Zhang E, Yin D, Sun M, Kong R, Liu X, You L et al. p53-regulated long non-coding RNA TUG1 affects cell proliferation in human non-small cell lung cancer, partly through epigenetically regulating HOXB7 expression. Cell Death Dis 2014; 5: e1243.

124 He L, He X, Lim LP, de Stanchina E, Xuan Z, Liang Y et al. A microRNA component of the p53 tumour suppressor network. Nature 2007; 447: 1130-1134.

125 Huarte M, Guttman M, Feldser D, Garber M, Koziol MJ, Kenzelmann-Broz D et al. A large intergenic noncoding RNA induced by p53 mediates global gene repression in the p53 response. Cell 2010; 142: 409-419.

126 Hung T, Wang Y, Lin MF, Koegel AK, Kotake Y, Grant GD et al. Extensive and coordinated transcription of noncoding RNAs within cell-cycle promoters. Nat Genet 2011; 43: 621-629.

127 Marín-Béjar O, Marchese FP, Athie A, Sánchez Y, González J, Segura V et al. Pint lincRNA connects the p53 pathway with epigenetic silencing by the Polycomb repressive complex 2. Genome Biol 2013; 14: R104.

128 Concepcion CP, Han YC, Mu P, Bonetti C, Yao E, D'Andrea A et al. Intact p53-dependent responses in miR-34-deficient mice. PLoS Genet 2012; 8: e1002797.

129 Dimitrova N, Zamudio JR, Jong RM, Soukup D, Resnick R, Sarma K et al. LincRNAp21 activates p21 in cis to promote polycomb target gene expression and to enforce the G1/S checkpoint. Mol Cell 2014; 54: 777-790.

130 Fei P, Wang W, Kim SH, Wang S, Burns TF, Sax JK et al. Bnip3L is induced by p53 under hypoxia, and its knockdown promotes tumor growth. Cancer Cell 2004; 6: 597-609.

131 Shirley SH, Rundhaug JE, Tian J, Cullinan-Ammann N, Lambertz I, Conti CJ et al. Transcriptional regulation of estrogen receptor-alpha by $\mathrm{p} 53$ in human breast cancer cells. Cancer Res 2009; 69: 3405-3414.

132 Laezza C, D’Alessandro A, Di Croce L, Picardi P, Ciaglia E, Pisanti S et al. p53 regulates the mevalonate pathway in human glioblastoma multiforme. Cell Death Dis 2015; 6: e1909.

133 Zhang C, Lin M, Wu R, Wang X, Yang B, Levine AJ et al. Parkin, a p53 target gene, mediates the role of p53 in glucose metabolism and the Warburg effect. Proc Natl Acad Sci USA 2011; 108: 16259-16264.

134 Cui R, Widlund HR, Feige E, Lin JY, Wilensky DL, Igras VE et al. Central role of p53 in the suntan response and pathologic hyperpigmentation. Cell 2007; 128: 853-864.

135 Charni M, Molchadsky A, Goldstein I, Solomon H, Tal P, Goldfinger N et al. Novel p53 target genes secreted by the liver are involved in non-cell-autonomous regulation. Cell Death Differ 2015; 23: 1-12.

136 Menendez D, Shatz M, Azzam K, Garantziotis S, Fessler MB, Resnick MA. The Tolllike receptor gene family is integrated into human DNA damage and p53 networks. PLos Genet 2011; 7: e1001360.

137 Gao W, Shen Z, Shang L, Wang X. Upregulation of human autophagy-initiation kinase ULK1 by tumor suppressor p53 contributes to DNA-damage-induced cell death. Cell Death Differ 2011; 18: 1598-1607.

138 loannidis JPA. Why most published research findings are false. PLoS Med 2005; 2: 0696-0701.

139 Lickwar CR, Mueller F, Hanlon SE, McNally JG, Lieb JD. Genome-wide proteinDNA binding dynamics suggest a molecular clutch for transcription factor function. Nature 2012; 484: 251-255.
140 Poorey K, Viswanathan R, Carver MN, Karpova TS, Cirimotich SM, McNally JG et al. Measuring chromatin interaction dynamics on the second time scale at singlecopy genes. Science 2013; 342: 369-372.

141 Baranello L, Kouzine F, Sanford S, Levens D. ChIP bias as a function of crosslinking time. Chromosom Res 2016; 24: 175-181.

142 Kastan MB, Onyekwere O, Sidransky D, Vogelstein B, Craig RW. Participation of p53 protein in the cellular response to DNA damage. Cancer Res 1991; 51: 6304-6311.

143 Lin D, Shields MT, Ullrich SJ, Appella E, Mercer WE. Growth arrest induced by wild-type $\mathrm{p} 53$ protein blocks cells prior to or near the restriction point in late G1 phase. Proc Natl Acad Sci USA 1992; 89: 9210-9214.

144 Agarwal ML, Agarwal A, Taylor WR, Stark GR. p53 controls both the G2/M and the G1 cell cycle checkpoints and mediates reversible growth arrest in human fibroblasts. Proc Natl Acad Sci USA 1995; 92: 8493-8497.

145 Abbas T, Dutta A. P21 in cancer: intricate networks and multiple activities. Nat Rev Cancer 2009; 9: 400-414.

146 Waldman T, Kinzler KW, Vogelstein B. P21 is necessary for the p53-mediated G1 arrest in human cancer cells. Cancer Res 1995; 55: 5187-5190.

147 Brugarolas J, Chandrasekaran C, Gordon Jl, Beach D, Jacks T, Hannon GJ. Radiation-induced cell cycle arrest compromised by p21 deficiency. Nature 1995; 377: 552-557.

148 Deng C, Zhang P, Wade Harper J, Elledge SJ, Leder P. Mice Lacking p21 CIP1/ WAF1 undergo normal development, but are defective in $\mathrm{G} 1$ checkpoint control. Cell 1995; 82: 675-684.

149 Bunz F, Dutriaux A, Lengauer C, Waldman T, Zhou S, Brown JP et al. Requirement for p53 and p21 to sustain G2 arrest after DNA damage. Science 1998; 282: 1497-1501.

150 Luo Y, Hurwitz J, Massagué J. Cell-cycle inhibition by independent CDK and PCNA binding domains in p21Cip1. Nature 1995; 375: 159-161.

151 Chen J, Jackson PK, Kirschner MW, Dutta A. Separate domains of p21 involved in the inhibition of Cdk kinase and PCNA. Nature 1995; 374: 386-388.

152 Harrington Ea, Bruce JL, Harlow E, Dyson N. pRB plays an essential role in cell cycle arrest induced by DNA damage. Proc Natl Acad Sci USA 1998; 95: 11945-11950.

153 Chang BD, Watanabe K, Broude EV, Fang J, Poole JC, Kalinichenko TV et al. Effects of p21Waf1/Cip1/Sdi1 on cellular gene expression: implications for carcinogenesis, senescence, and age-related diseases. Proc Natl Acad Sci USA 2000; 97: 4291-4296.

154 Guardavaccaro D, Corrente G, Covone F, Micheli L, D'Agnano I, Starace G et al. Arrest of $\mathrm{G}(1)-S$ progression by the p53-inducible gene $P C 3$ is $R b$ dependent and relies on the inhibition of cyclin D1 transcription. Mol Cell Biol 2000; 20: 1797-1815.

155 Rouault J-P, Falette N, Guéhenneux F, Guillot C, Rimokh R, Wang Q et al. Identification of BTG2, an antiproliferative p53-dependent component of the DNA damage cellular response pathway. Nat Genet 1996; 14: 482-486.

156 Wang XW, Zhan Q, Coursen JD, Khan MA, Kontny HU, Yu L et al. GADD45 induction of a G2/M cell cycle checkpoint. Proc Natl Acad Sci USA 1999; 96: 3706-3711.

157 Chan TA, Hermeking H, Lengauer C, Kinzler KW, Vogelstein B. 14-3-3Sigma is required to prevent mitotic catastrophe after DNA damage. Nature 1999; 401: 616-620.

158 Welcker M, Clurman BE. FBW7 ubiquitin ligase: a tumour suppressor at the crossroads of cell division, growth and differentiation. Nat Rev Cancer 2008; 8: 83-93.

159 Mao J-H, Perez-losada J, Wu D, Delrosario R, Tsunematsu R, Nakayama KI et al. Fbxw7/Cdc4 is a p53-dependent, haploinsufficient tumour suppressor gene. Nature 2004; 432: 775-779.

160 Rashi-Elkeles S, Elkon R, Shavit S, Lerenthal Y, Linhart C, Kupershtein A et al. Transcriptional modulation induced by ionizing radiation: P53 remains a central player. Mol Oncol 2011; 5: 336-348.

161 Shin TH, Paterson AJ, Kudlow JE. p53 stimulates transcription from the human transforming growth factor alpha promoter: a potential growth-stimulatory role for p53. Mol Cell Biol 1995; 15: 4694-4701.

162 Sengupta S, Harris CC. p53: traffic cop at the crossroads of DNA repair and recombination. Nat Rev Mol Cell Biol 2005; 6: 44-55.

163 Gatz SA, Wiesmuller L. p53 in recombination and repair. Cell Death Differ 2006; 13: 1003-1016.

164 Christophorou MA, Ringshausen I, Finch AJ, Swigart LB, Evan GI. The pathological response to DNA damage does not contribute to p53-mediated tumour suppression. Nature 2006; 443: 214-217.

165 Tan T, Chu G. p53 binds and activates the xeroderma pigmentosum DDB2 gene in humans but not mice. Mol Cell Biol 2002; 22: 3247-3254.

166 Adimoolam S, Ford JM. p53 and DNA damage-inducible expression of the xeroderma pigmentosum group C gene. Proc Natl Acad Sci USA 2002; 99: 12985-12990. 
167 Moldovan GL, Pfander B, Jentsch S. PCNA, the maestro of the replication fork. Cell 2007; 129: 665-679.

168 Li YY, Wang L, Lu CD. An E2F site in the 5'-promoter region contributes to serumdependent up-regulation of the human proliferating cell nuclear antigen gene. FEBS Lett 2003; 544: 112-118.

169 Shivakumar CV, Brown DR, Deb S, Deb SP. Wild-type human P53 transactivates the human proliferating cell nuclear antigen promoter. Mol Cell Biol 1995; 15: 6785-6793.

170 Liu G, Chen X. DNA polymerase eta, the product of the xeroderma pigmentosum variant gene and a target of p53, modulates the DNA damage checkpoint and p53 activation. Mol Cell Biol 2006; 26: 1398-1413.

171 Lerner LK, Francisco G, Soltys DT, Rocha CRR, Quinet A, Vessoni AT et al. Predominant role of DNA polymerase eta and p53-dependent translesion synthesis in the survival of ultraviolet-irradiated human cells. Nucleic Acids Res 2016; e-pub ahead of print 2 December 2016; doi:10.1093/nar/gkw1196.

172 Warnick CT, Dabbas B, Ford CD, Strait KA. Identification of a p53 response element in the promoter region of the $\mathrm{hMSH} 2$ gene required for expression in A2780 ovarian cancer cells. J Biol Chem 2001; 276: 27363-27370.

173 Arias-Lopez C, Lazaro-Trueba I, Kerr P, Lord CJ, Dexter T, Iravani M et al. p53 modulates homologous recombination by transcriptional regulation of the RAD51 gene. EMBO Rep 2006; 7: 219-224.

174 Jaber S, Toufektchan E, Lejour V, Bardot B, Toledo F. p53 downregulates the Fanconi anaemia DNA repair pathway. Nat Commun 2016; 7: 11091.

175 Chen J, Sadowski I. Identification of the mismatch repair genes PMS2 and MLH1 as p53 target genes by using serial analysis of binding elements. Proc Natl Acad Sci USA 2005; 102: 4813-4818.

176 Haupt S, Berger M, Goldberg Z, Haupt Y. Apoptosis-the p53 network. J Cell Sci 2003; 116: 4077-4085.

177 Elmore S. Apoptosis: a review of programmed cell death. Toxicol Pathol 2007; 35: 495-516.

178 Locksley RM, Killeen N, Lenardo MJ. The TNF and TNF receptor superfamilies: integrating mammalian biology. Cell 2001; 104: 487-501.

179 Sax JK, El-Deiry WS. Identification and characterization of the cytoplasmic protein TRAF4 as a p53-regulated proapoptotic gene. J Biol Chem 2003; 278: 36435-36444.

180 Reczek EE, Flores ER, Tsay AS, Attardi LD, Jacks T. Multiple response elements and differential p53 binding control Perp expression during apoptosis. Mol Cancer Res 2003; 1: 1048-1057.

181 Nakano K, Vousden KH. PUMA, a novel proapoptotic gene, is induced by p53. Mol Cell 2001; 7: 683-694

182 Hudson CD, Morris PJ, Latchman DS. Brn-3a transcription factor blocks p53 mediated activation of pro-apoptotic target genes, Noxa and Bax, in vitro and in vivo to determine cell fate. J Biol Chem 2004; 280: 11851-11858.

183 Robles Al, Bemmels NA, Foraker AB, Harris CC. APAF-1 is a transcriptional target of p53 in DNA damage-induced apoptosis advances in brief APAF-1 is a transcriptional target of p53 in DNA damage-induced apoptosis. Cancer Res 2001; 61: 6660-6664.

184 Fortin A, Cregan SP, MacLaurin JG, Kushwaha N, Hickman ES, Thompson CS et al. APAF1 is a key transcriptional target for p53 in the regulation of neuronal cell death. J Cell Biol 2001; 155: 207-216.

185 Rozenfeld-Granot G, Krishnamurthy J, Kannan K, Toren A, Amariglio N, Givol D et al. A positive feedback mechanism in the transcriptional activation of Apaf-1 by $\mathrm{p} 53$ and the coactivator Zac-1. Oncogene 2002; 21: 1469-1476.

186 Obeid LM, Linardic CM, Karolak LA, Hannun YA. Programmed cell death induced by ceramide. Science 1993; 259: 1769-1771.

187 Fekry B, Jeffries KA, Esmaeilniakooshkghazi A, Ogretmen B, Krupenko SA, Krupenko $\mathrm{Nl}$ et al. CerS6 is a novel transcriptional target of p53 protein activated by non-genotoxic stress. J Biol Chem 2016; 291: 16586-16596.

188 Panjarian S, Kozhaya L, Arayssi S, Yehia M, Bielawski J, Bielawska A et al. De novo N-palmitoylsphingosine synthesis is the major biochemical mechanism of ceramide accumulation following p53 up-regulation. Prostaglandins Other Lipid Mediat 2008; 86: 41-48.

189 Park WR, Nakamura Y. p53CSV, a novel p53-inducible gene involved in the p53-dependent cell-survival pathway. Cancer Res 2005; 65: 1197-1206.

190 Budhram-Mahadeo V, Morris PJ, Smith MD, Midgley CA, Boxer LM, Latchman DS. p53 suppresses the activation of the Bcl-2 promoter by the Brn-3a POU family transcription factor. J Biol Chem 1999; 274: 15237-15244.

191 Wu Y, Mehew JW, Heckman Ca, Arcinas M, Boxer LM. Negative regulation of bcl-2 expression by p53 in hematopoietic cells. Oncogene 2001; 20: 240-251.

192 Sax JK, Fei P, Murphy ME, Bernhard E, Korsmeyer SJ, El-Deiry WS. BID regulation by $\mathrm{p} 53$ contributes to chemosensitivity. Nat Cell Biol 2002; 4: 842-849.

193 Stambolsky P, Weisz L, Shats I, Klein Y, Goldfinger N, Oren M et al. Regulation of AlF expression by p53. Cell Death Differ 2006; 13: 2140-2149.

194 Vousden KH, Ryan KM. p53 and metabolism. Nat Rev Cancer 2009; 9: 691-700.
195 Kruiswijk F, Labuschagne CF, Vousden KH. p53 in survival, death and metabolic health: a lifeguard with a licence to kill. Nat Rev Mol Cell Biol 2015; 16: 393-405.

196 Baudot AD, Crighton D, O’Prey J, Somers J, Sierra Gonzalez P, Ryan KM. p53 directly regulates the glycosidase FUCA1 to promote chemotherapy-induced cell death. Cell Cycle 2016; 15: 2299-2308.

197 Suzuki S, Tanaka T, Poyurovsky MV, Nagano H, Mayama T, Ohkubo S et al. Phosphate-activated glutaminase (GLS2), a p53-inducible regulator of glutamine metabolism and reactive oxygen species. Proc Natl Acad Sci USA 2010; 107: $7461-7466$.

198 Hu W, Zhang C, Wu R, Sun Y, Levine A, Feng Z. Glutaminase 2, a novel p53 target gene regulating energy metabolism and antioxidant function. Proc Natl Acad Sci USA 2010; 107: 7455-7460.

199 Böhlig L, Friedrich M, Engeland K. p53 activates the PANK1/miRNA-107 gene leading to downregulation of CDK6 and p130 cell cycle proteins. Nucleic Acids Res 2011; 39: 440-453.

200 Wang SJ, Yu G, Jiang L, Li T, Lin Q, Tang Y et al. p53-dependent regulation of metabolic function through transcriptional activation of pantothenate kinase1 gene. Cell Cycle 2013; 12: 753-761.

201 Feng Z, Hu W, de Stanchina E, Teresky AK, Jin S, Lowe S et al. The regulation of AMPK beta1, TSC2, and PTEN expression by p53: stress, cell and tissue specificity, and the role of these gene products in modulating the IGF-1-AKT-mTOR pathways. Cancer Res 2007; 67: 3043-3053.

202 Liu G, Chen X. The ferredoxin reductase gene is regulated by the p53 family and sensitizes cells to oxidative stress-induced apoptosis. Oncogene 2002; 21: 7195-7204.

203 Matoba S, Kang JG, Patino WD, Wragg A, Boehm M, Gavrilova O et al. p53 regulates mitochondrial respiration. Science 2006; 312: 1650-1653.

204 Assaily W, Rubinger DA, Wheaton K, Lin Y, Ma W, Xuan W et al. ROS-mediated p53 induction of Lpin1 regulates fatty acid oxidation in response to nutritional stress. Mol Cell 2011; 44: 491-501.

205 Sanchez-Macedo N, Feng J, Faubert B, Chang N, Elia A, Rushing EJ et al. Depletion of the novel p53-target gene carnitine palmitoyltransferase $1 \mathrm{C}$ delays tumor growth in the neurofibromatosis type I tumor model. Cell Death Differ 2013; 20: 659-668.

206 Kawauchi K, Araki K, Tobiume K, Tanaka N. p53 regulates glucose metabolism through an IKK-NF-kappaB pathway and inhibits cell transformation. Nat Cell Biol 2008; 10: 611-618.

207 Schwartzenberg-Bar-Yoseph F, Armoni M, Karnieli E. The tumor suppressor p53 down-regulates glucose transporters GLUT1 and GLUT4 gene expression. Cancer Res 2004; 64: 2627-2633.

208 Tasdemir E, Maiuri MC, Galluzzi L, Vitale I, Djavaheri-Mergny M, D’Amelio M et al. Regulation of autophagy by cytoplasmic p53. Nat Cell Biol 2008; 10: 676-687.

209 Crighton D, Wilkinson S, O'Prey J, Syed N, Smith P, Harrison PR et al. DRAM, a p53-induced modulator of autophagy, is critical for apoptosis. Cell 2006; 126: 121-134.

210 Feng $Z$, Zhang $H$, Levine AJ, Jin S. The coordinate regulation of the p53 and mTOR pathways in cells. Proc Natl Acad Sci USA 2005; 102: 8204-8209.

211 Budanov AV, Karin M. p53 target genes sestrin1 and sestrin2 connect genotoxic stress and mTOR signaling. Cell 2008; 134: 451-460.

212 Budde A, Grummt I. p53 represses ribosomal gene transcription. Oncogene 1999; 18: 1119-1124.

213 Zhai W, Comai L. Repression of RNA polymerase I transcription by the tumor suppressor p53. Mol Cell Biol 2000; 20: 5930-5938.

214 Golomb L, Bublik DR, Wilder S, Nevo R, Kiss V, Grabusic K et al. Importin 7 and exportin 1 Link c-Myc and p53 to regulation of ribosomal Biogenesis. Mol Cell 2012; 45: 222-232.

215 Loayza-Puch F, Drost J, Rooijers K, Lopes R, Elkon R, Agami R. p53 induces transcriptional and translational programs to suppress cell proliferation and growth. Genome Biol 2013; 14: R32.

216 Harris SL, Levine AJ. The p53 pathway: positive and negative feedback loops. Oncogene 2005; 24: 2899-2908.

217 Haupt $\mathrm{Y}$, Maya R, Kazaz A, Oren M. Mdm2 promotes the rapid degradation of p53. Nature 1997; 387: 296-299.

218 Okamoto K, Li H, Jensen MR, Zhang T, Taya Y, Thorgeirsson SS et al. Cyclin G recruits PP2A to dephosphorylate Mdm2. Mol Cell 2002; 9: 761-771.

219 Okamoto K, Beach D. Cyclin G is a transcriptional target of the p53 tumor suppressor protein. EMBO J 1994; 13: 4816-4822.

220 Lu X, Nannenga B, Donehower LA. PPM1D dephosphorylates Chk1 and p53 and abrogates cell cycle checkpoints. Genes Dev 2005; 19: 1162-1174.

221 Lindqvist A, de Bruijn M, Macurek L, Brás A, Mensinga A, Bruinsma W et al. Wip1 confers $G 2$ checkpoint recovery competence by counteracting p53-dependent transcriptional repression. EMBO J 2009; 28: 3196-3206.

222 De Stanchina E, Querido E, Narita M, Davuluri RV, Pandolfi PP, Ferbeyre G et al. PML is a direct p53 target that modulates p53 effector functions. Mol Cell 2004; 13: $523-535$. 
223 Obad S, Brunnström H, Vallon-Christersson J, Borg A, Drott K, Gullberg U. Staf50 is a novel p53 target gene conferring reduced clonogenic growth of leukemic U-937 cells. Oncogene 2004; 23: 4050-4059.

224 Elabd S, Meroni G, Blattner C. TRIMming p53's anticancer activity. Oncogene 2016; 35: 5577-5584.

225 Polager S, Ginsberg D. p53 and E2f: partners in life and death. Nat Rev Cancer 2009; 9: 738-748.

226 Bates S, Phillips AC, Clark PA, Stott F, Peters G, Ludwig RL et al. p14ARF links the tumour suppressors RB and p53. Nature 1998; 395: 124-125.

227 Chen D, Pacal M, Wenzel P, Knoepfler PS, Leone G, Bremner R. Division and apoptosis of E2f-deficient retinal progenitors. Nature 2009; 462: 925-929.

228 Fiucci G, Beaucourt S, Duflaut D, Lespagnol A, Stumptner-Cuvelette P, Géant A et al. Siah-1b is a direct transcriptional target of p53: identification of the functional p53 responsive element in the siah-1b promoter. Proc Natl Acad Sci USA 2004; 101: 3510-3515.

229 Leng RP, Lin Y, Ma W, Wu H, Lemmers B, Chung S et al. Pirh2, a p53-induced ubiquitin-protein ligase, promotes p53 degradation. Cell 2003; 112: 779-791.

230 Dornan D, Bheddah S, Newton K, Inice W, Frantz GD, Dowd P et al. COP1, the negative regulator of $\mathrm{p} 53$, is overexpressed in breast and ovarian adenocarcinomas. Cancer Res 2004; 64: 7226-7230.

231 Vousden $\mathrm{KH}$, Prives $\mathrm{C}$. Blinded by the light: the growing complexity of p53. Cell 2009; 137: 413-431.

232 Engeland K. Simplify p53: just an activator. Oncotarget 2015; 6: 3-4.

233 Kawase T, Ohki R, Shibata T, Tsutsumi S, Kamimura N, Inazawa J et al. PH domainonly protein PHLDA3 is a p53-regulated repressor of Akt. Cell 2009; 136: $535-550$

234 Min S-H, Kim DM, Heo Y-S, Kim Y-I, Kim HM, Kim J et al. New p53 target, phosphatase of regenerating liver 1 (PRL-1) downregulates p53. Oncogene 2009; 28: $545-554$

235 Zou ZQ, Gao CL, Nagaich AK, Connell T, Saito S, Moul JW et al. p53 regulates the expression of the tumor suppressor gene maspin. J Biol Chem 2000; 275: 6051-6054.

236 Bornstein C, Brosh R, Molchadsky A, Madar S, Kogan-Sakin I, Goldstein I et al. SPATA18, a spermatogenesis-associated gene, is a novel transcriptional target of p53 and p63. Mol Cell Biol 2011; 31: 1679-1689.

237 Taura M, Eguma A, Suico MA, Shuto T, Koga T, Komatsu K et al. p53 regulates Toll-like receptor 3 expression and function in human epithelial cell lines. Mol Cell Biol 2008; 28: 6557-6567.

238 Choi W, Cogdell D, Feng Y, Hamilton SR, Zhang W. Transcriptional activation of the carboxylesterase 2 gene by the p53 pathway. Cancer Biol Ther 2006; 5: $1450-1456$.

239 Hearnes JM, Mays DJ, Schavolt KL, Tang L, Jiang $X$, Pietenpol JA Chromatin immunoprecipitation-based screen to identify functional genomic binding sites for sequence-specific transactivators. Mol Cell Biol 2005; 25: 10148-10158.

240 Vrba L, Junk DJ, Novak P, Futscher BW. p53 induces distinct epigenetic states at its direct target promoters. BMC Genomics 2008; 9: 486.

241 Mashimo T, Watabe M, Hirota S, Hosobe S, Miura K, Tegtmeyer PJ et al. The expression of the KAl1 gene, a tumor metastasis suppressor, is directly activated by p53. Proc Natl Acad Sci USA 1998; 95: 11307-11311.

242 Brown L, Ongusaha PP, Kim H-GG, Nuti S, Mandinova A, Lee JW et al. CDIP, a novel pro-apoptotic gene, regulates TNFalpha-mediated apoptosis in a p53dependent manner. EMBO J 2007; 26: 3410-3422.

243 Wilhelm MT, Méndez-Vidal C, Wiman KG. Identification of functional p53-binding motifs in the mouse wig-1 promoter. FEBS Lett 2002; 524: 69-72.

244 Azzam G, Wang X, Bell D, Murphy ME. CSF1 is a novel p53 target gene whose protein product functions in a feed-forward manner to suppress apoptosis and enhance p53-mediated growth arrest. PLoS One 2013; 8: e74297.

245 Chau BN, Diaz RL, Saunders MA, Cheng C, Chang AN, Warrener P et al. Identification of SULF2 as a novel transcriptional target of p53 by use of integrated genomic analyses. Cancer Res 2009; 69: 1368-1374.

246 Asano Y, Kawase T, Okabe A, Tsutsumi S, Ichikawa H, Tatebe S et al. IER5 generates a novel hypo-phosphorylated active form of HSF1 and contributes to tumorigenesis. Sci Rep 2016; 6: 19174

247 Zhang Y, Qian Y, Lu W, Chen X. The G protein-coupled receptor 87 is necessary for p53-dependent cell survival in response to genotoxic stress. Cancer Res 2009; 69: 6049-6056.

248 Tanikawa C, Ueda K, Nakagawa H, Yoshida N, Nakamura Y, Matsuda K. Regulation of protein Citrullination through p53/PADI4 network in DNA damage response. Cancer Res 2009; 69: 8761-8769.

249 Zhang C, Gao C, Kawauchi J, Hashimoto Y, Tsuchida N, Kitajima S. Transcriptional activation of the human stress-inducible transcriptional repressor ATF3 gene promoter by p53. Biochem Biophys Res Commun 2002; 297: 1302-1310.

250 Yan J, Jiang J, Lim CA, Wu Q, Ng H-H, Chin K-C. BLIMP1 regulates cell growth through repression of p53 transcription. Proc Natl Acad Sci USA 2007; 104: 1841-1846.
251 Polyak K, Xia Y, Zweier JL, Kinzler KW, Vogelstein B. A model for p53-induced apoptosis. Nature 1997; 389: 300-305.

252 Contente A, Dittmer A, Koch MC, Roth J, Dobbelstein M. A polymorphic microsatellite that mediates induction of PIG3 by p53. Nat Genet 2002; 30 315-320.

253 Zhang X, He Y, Lee KH, Dubois W, Li Z, Wu X et al. Rap2b, a novel p53 target, regulates p53-mediated pro-survival function. Cell Cycle 2013; 12: 1279-1291.

254 Okamura S, Arakawa H, Tanaka T, Nakanishi H, Ng CC, Taya Y et al. p53DINP1, a p53-inducible gene, regulates p53-dependent apoptosis. Mol Cell 2001; 8: 85-94.

255 Goldstein I, Ezra O, Rivlin N, Molchadsky A, Madar S, Goldfinger N et al. p53, a novel regulator of lipid metabolism pathways. J Hepatol 2012; 56: 656-662.

256 Tanikawa C, Furukawa Y, Yoshida N, Arakawa H, Nakamura Y, Matsuda K. XEDAR as a putative colorectal tumor suppressor that mediates p53-regulated anoikis pathway. Oncogene 2009; 28: 3081-3092.

257 Zhang C, Liu J, Wu R, Liang Y, Lin M, Liu J et al. Tumor suppressor p53 negatively regulates glycolysis stimulated by hypoxia through its target RRAD. Oncotarget 2014; 5: 5535-5546.

258 Jin YJ, Wang J, Qiao C, Hei TK, Brandt-Rauf PW, Yin Y. A novel mechanism for p53 to regulate its target gene ECK in signaling apoptosis. Mol Cancer Res 2006; 4 : 769-778.

259 Jackson RS, Cho YJ, Stein S, Liang P. CYFIP2, a direct p53 target, is leptomycin-B sensitive. Cell Cycle 2007; 6: 95-103.

$260 \mathrm{Hu} \mathrm{W}$, Feng Z, Teresky AK, Levine AJ. p53 regulates maternal reproduction through LIF. Nature 2007; 450: 721-724.

261 Mathieu M, Lapierre I, Brault K, Raymond M. Aromatic hydrocarbon receptor (AhR) nuclear translocator- and p53-mediated Induction of the murine multidrug resistance mdr1 gene by 3-methylcholanthrene and benzo (a) pyrene in hepatoma cells. J Biol Chem 2001; 276: 4819-4827.

262 Mirza A, Wu Q, Wang L, McClanahan T, Bishop WR, Gheyas F et al. Global transcriptional program of p53 target genes during the process of apoptosis and cell cycle progression. Oncogene 2003; 22: 3645-3654.

263 Jackson MW, Agarwal MK, Yang J, Bruss P, Uchiumi T, Agarwal ML et al. p130/ p107/p105Rb-dependent transcriptional repression during DNA-damageinduced cell-cycle exit at G2. J Cell Sci 2005; 118: 1821-1832.

264 Hoffman WH, Biade S, Zilfou JT, Chen J, Murphy M. Transcriptional repression of the anti-apoptotic survivin gene by wild type p53. J Biol Chem 2002; 277: 3247-3257.

265 Estève P-O, Chin HG, Pradhan S. Human maintenance DNA (cytosine-5)methyltransferase and p53 modulate expression of p53-repressed promoters. Proc Natl Acad Sci USA 2005; 102: 1000-1005.

266 Raj D, Liu T, Samadashwily G, Li F, Grossman D. Survivin repression by p53, Rb and E2F2 in normal human melanocytes. Carcinogenesis 2008; 29: 194-201.

267 Nabilsi NH, Broaddus RR, Loose DS. DNA methylation inhibits p53-mediated survivin repression. Oncogene 2009; 28: 2046-2050.

268 Mirza A, McGuirk M, Hockenberry TN, Wu Q, Ashar H, Black S et al. Human survivin is negatively regulated by wild-type p53 and participates in p53-dependent apoptotic pathway. Oncogene 2002; 21: 2613-2622.

269 Feng X, Liu X, Zhang W, Xiao W. p53 directly suppresses BNIP3 expression to protect against hypoxia-induced cell death. EMBO J 2011; 30: 3397-3415.

270 Innocente SA, Lee JM. p73 is a p53-independent, Sp1-dependent repressor of cyclin B1 transcription. Biochem Biophys Res Commun 2005; 329 . 713-718.

271 Lipski R, Lippincott DJ, Durden BC, Kaplan AR, Keiser HE, Park JH et al. p53 dimers associate with a head-to-tail response element to repress cyclin $B$ transcription. PLoS One 2012; 7: e42615.

272 Zeilstra J, Joosten SPJ, Vermeulen L, Koster J, Medema JP, Versteeg R et al. CD44 expression in intestinal epithelium and colorectal cancer is independent of p53 status. PLoS One 2013; 8: e72849.

273 Banerjee T, Nath S, Roychoudhury S. DNA damage induced p53 downregulates Cdc20 by direct binding to its promoter causing chromatin remodeling. Nucleic Acids Res 2009; 37: 2688-2698.

274 Dalvai M, Mondesert O, Bourdon J-C, Ducommun B, Dozier C. Cdc25B is negatively regulated by $\mathrm{p} 53$ through $\mathrm{Sp} 1$ and NF-Y transcription factors. Oncogene 2011; 30: 2282-2288.

275 St Clair S, Giono L, Varmeh-Ziaie S, Resnick-Silverman L, Liu WJ, Padi A et al. DNA damage-induced downregulation of $\mathrm{Cdc} 25 \mathrm{C}$ is mediated by p53 via two independent mechanisms: One involves direct binding to the $\mathrm{cdc} 25 \mathrm{C}$ promoter. $\mathrm{Mol}$ Cell 2004; 16: 725-736.

276 Le Gac G, Estève PO, Ferec C, Pradhan S. DNA damage-induced down-regulation of human $\mathrm{Cdc} 25 \mathrm{C}$ and $\mathrm{Cdc} 2$ is mediated by cooperation between $\mathrm{p} 53$ and maintenance DNA (cytosine-5) methyltransferase. J Biol Chem 2006; 281 24161-24170.

277 Ceribelli M, Alcalay M, Viganò MA, Mantovani R. Repression of new p53 targets revealed by ChIP on chip experiments. Cell Cycle 2006; 5: 1102-1110. 
278 Bansal N, Kadamb R, Mittal S, Vig L, Sharma R, Dwarakanath BS et al. Tumor suppressor protein p53 recruits human Sin3B/HDAC1 complex for downregulation of its target promoters in response to genotoxic stress. PLoS One 2011; 6: e26156.

279 Scoumanne A, Chen X. The epithelial cell transforming sequence 2, a guanine nucleotide exchange factor for Rho GTPases, is repressed by p53 via protein methyltransferases and is required for G1-S transition. Cancer Res 2006; 66: 6271-6279.

280 Cotton N, Hampshire N. Tissue-specific stem cells p53 directly represses Id 2 to inhibit the proliferation of neural progenitor cells. Stem Cells 2011; 29: 1090-1101.

281 Wang B, Feng P, Xiao Z, Ren EC. LIM and SH3 protein 1 (Lasp1) is a novel p53 transcriptional target involved in hepatocellular carcinoma. J Hepatol 2009; 50: 528-537.

282 Chun ACS, Jin DY. Transcriptional regulation of mitotic checkpoint gene MAD1 by p53. J Biol Chem 2003; 278: 37439-37450.

283 Nabilsi NH, Ryder DJ, Peraza-Penton AC, Poudyal R, Loose DS, Kladde MP. Local depletion of DNA methylation identifies a repressive $\mathrm{p} 53$ regulatory region in the NEK2 promoter. J Biol Chem 2013; 288: 35940-35951.

284 Saifudeen Z, Marks J, Du H, El-Dahr SS. Spatial repression of PCNA by p53 during kidney development. Am JPhysiol Ren Physiol 2002; 283: F727-F733.

285 Morris GF, Bischoff JR, Mathews MB. Transcriptional activation of the human proliferating-cell nuclear antigen promoter by p53. Proc Natl Acad Sci USA 1996; 93: 895-899.

286 McKenzie L, King S, Marcar L, Nicol S, Dias SS, Schumm K et al. p53-dependent repression of polo-like kinase-1 (PLK1). Cell Cycle 2010; 9: 4200-4212.
287 Zhou Z, Cao JX, Li SY, An GS, Ni JH, Jia HT. p53 Suppresses E2F1-dependent PLK1 expression upon DNA damage by forming p53-E2F1-DNA complex. Exp Cell Res 2013; 319: 3104-3115.

$288 \mathrm{Li} \mathrm{BQ}$, Lee MYW. Transcriptional regulation of the human DNA polymerase delta catalytic subunit gene POLD1 by p53 tumor suppressor and Sp1. J Biol Chem 2001; 276: 29729-29739.

289 Li C, Lin M, Liu J. Identification of PRC1 as the p53 target gene uncovers a novel function of p53 in the regulation of cytokinesis. Oncogene 2004; 23: 9336-9347.

290 Golubovskaya V, Kaur A, Cance W. Cloning and characterization of the promoter region of human focal adhesion kinase gene: nuclear factor kappa $B$ and p53 binding sites. Biochim Biophys Acta 2004; 1678: 111-125.

291 Rueda-Rincon N, Bloch K, Derua R, Vyas R, Harms A, Hankemeier T et al. p53 attenuates AKT signaling by modulating membrane phospholipid composition. Oncotarget 2015; 6: 21240-21254.

(c) (1) (2) This work is licensed under a Creative Commons AttributionBY NG SA NonCommercial-ShareAlike 4.0 International License. The images or other third party material in this article are included in the article's Creative Commons license, unless indicated otherwise in the credit line; if the material is not included under the Creative Commons license, users will need to obtain permission from the license holder to reproduce the material. To view a copy of this license, visit http:// creativecommons.org/licenses/by-nc-sa/4.0/

(c) The Author(s) 2017

Supplementary Information accompanies this paper on the Oncogene website (http://www.nature.com/onc) 